Article

\title{
Future Irrigation Water Requirements of the Main Crops Cultivated in the Niger River Basin
}

\author{
Abdoulaye Oumarou Abdoulaye ${ }^{1}$, Haishen Lu ${ }^{1, *}$, Yonghua Zhu ${ }^{1}$ and Yousef Alhaj Hamoud ${ }^{2} \mathbb{D}$ \\ 1 State Key Laboratory of Hydrology-Water Resources and Hydraulic Engineering, \\ College of Hydrology and Water Resources, Hohai University, Nanjing 210098, China; \\ d2016002@hhu.edu.cn (A.O.A.); zhuyonghua@hhu.edu.cn (Y.Z.) \\ 2 College of Agricultural Science and Engineering, Hohai University, Nanjing 210098, China; \\ yousef-hamoud11@hhu.edu.cn \\ * Correspondence: 1vhaishen@hhu.edu.cn
}

Citation: Abdoulaye, A.O.; Lu, H.; Zhu, Y.; Hamoud, Y.A. Future Irrigation Water Requirements of the Main Crops Cultivated in the Niger River Basin. Atmosphere 2021, 12, 439. https://doi.org/10.3390/atmos12040439

\section{Academic Editors:}

Ioannis Charalampopoulos and Spyridon Paparrizos

Received: 4 February 2021

Accepted: 20 March 2021

Published: 29 March 2021

Publisher's Note: MDPI stays neutral with regard to jurisdictional claims in published maps and institutional affiliations.

Copyright: (c) 2021 by the authors. Licensee MDPI, Basel, Switzerland. This article is an open access article distributed under the terms and conditions of the Creative Commons Attribution (CC BY) license (https:/ / creativecommons.org/licenses/by/ $4.0 /)$.

\begin{abstract}
Precise agricultural predictions of climate change effects on crop water productivity are essential to ensure food security and alleviate water scarcity. In this regard, the present study provides an overview of the future impacts of climate change on the irrigation of agricultural products such as rice, millet, maize, cassava, sorghum, and sugar cane. These crops are some of the most-consumed foodstuffs in countries of the Niger River basin. This study is realized throughout 2020 to 2080, and three Global Climate Models (GCMs) (CSIRO, MIROC5, and ECHAM. MPI-ESM-LR) have been used. The GCMs data have been provided by the IPCC 5 database. The irrigation water requirement for each crop was calculated using Smith's CROPWAT approach. The Penman-Monteith equation recommended by the FAO was used to calculate the potential evapotranspiration. The inter-annual results of the IWR, according to the set of models selected, illustrate that the largest quantities of water used for irrigation are generally observed between January and March, and the lowest quantities are the most often seen between July and September. The majority of models also illustrate a peak in the IWR between March and April. Sorghum and millet are the crops consuming the least amount of water for irrigation; followed by cassava, then rice and corn, and finally sugar cane. The most significant IWRs, which have been predicted, will be between $16.3 \mathrm{~mm} /$ day (MIROC5 model, RCP 4.5) and $45.9 \mathrm{~mm} /$ day (CSIRO model, RCP 4.5), particularly in Mali, Niger, Algeria, and rarely in Burkina-Faso (CSIRO model, RCP4.5 and 8.5). The lowest IWRs predicted by the models will be from $1.29 \mathrm{~mm}$ /day (MIROC5 model, RCP 4.5) to $33.4 \mathrm{~mm} /$ day (CSIRO model, RCP 4.5); they will be observed according to the models in Guinea, southern Mali, Ivory Coast, center and southern Nigeria, and Cameroon. However, models predict sugarcane to be the plant with the highest IWR, between $0.25 \mathrm{~mm} /$ day (Benin in 2020-2040) and $25.66 \mathrm{~mm} /$ day (Chad in 2060-2080). According to the models' predictions, millet is the crop with the most IWR, between $0.20 \mathrm{~mm} /$ day (Benin from 2020 to 2060) and $19.37 \mathrm{~mm} /$ day (Chad in 2060-2080). With the results of this study, the countries belonging to the Niger River basin can put in place robust policies in the water resources and agriculture sectors, thus ensuring food security and high-quality production of staple crops, and avoiding water scarcity while facing the negative impacts of climate change.
\end{abstract}

Keywords: climate change scenarios; global climate models (GCM); irrigation water request; Niger River basin

\section{Introduction}

Climate change causes wide-reaching concerns and is described by fluctuating patterns in rainfall, rising temperatures, and extreme climate events [1,2]. The consequences of climate change-such as increases in the global average temperature as well as modifications of the rainy seasons-on ecosystems, biodiversity, and human systems throughout the world, are undoubtedly verifiable [3]. Globally, the agricultural sector faces critical food security issues and is threatened by the scarcity of freshwater, both on the surface and 
underground, due to the recurring problem of climate change, which includes changes in agro-ecological conditions [4]. Therefore, agricultural production systems are directly and indirectly affected by climate change in various ways, i.e., by influencing growth and income distribution as well as by bringing about variations in crop yields [5]. Thus, to ensure food security and cope with the scarcity of freshwater, it is essential to increase water productivity under varying climatic conditions, especially in the coming decades. Therefore, the emphasis on the responses of crops to climatic variations is of growing interest.

Agro-ecological changes are extremely linked to recent changes in climate, drought, and rapid urbanization [6]. The continent of Africa has been singled out as the continent most affected by the effects of climate change [7]. Rice, millet, maize, cassava, sorghum, and sugar cane are among the most-consumed foodstuffs in the countries of the Niger River basin. In terms of river flow, the Niger River is ranked 27th among the world's largest rivers. The Niger River has an annual discharge between $193 \mathrm{~km}^{3} / \mathrm{yr}$ in Gaya (Niger) [8] and $183 \mathrm{~km}^{3} / \mathrm{yr}$ at the confluence of the Niger and Benue rivers [9]. Therefore, it is classified in the category of very large rivers. Irrigation remains poorly developed; only $15 \%$ of the cultivated area is rainfed [9]. However, with regard to recent changes in climate and restrictions of freshwater resources, irrigated agricultural production systems are needed to ensure continuous agricultural production while improving the efficiency of crop water use. Therefore, an understanding of the water use and productivity responses of each crop and its links to the varying agro-environment is required to recognize the proper water requests for crop production under increasingly limited freshwater resources; thus, simulation of the irrigation water requirements of cereal crops is important to reach this objective.

Many studies have been conducted to enhance the understanding of the impacts of climate change on plant health and the water use efficiency of crops [7,10-16]. However, the impact of climate change on the yield and irrigation water requirements of crops cultivated under varied agro-ecological conditions is not well understood. Therefore, to sustain cereal food production under a changing climate, the future irrigation water requirements should be evaluated and predicted. Thus, researchers have paid much attention to crop simulation instead of to field trials, as field experimentation is time-consuming and expensive. Global climate models are currently the only tools that take into account the complex set of processes that will determine future global and regional climate change [17]. Based on different climate models, several studies have been carried out to assess and predict the effects of climate change on agriculture. One of the research topics present in these studies is the problem of climate change affecting irrigation [18-21]. Irrigation is one of the agricultural sectors that consumes the most water for production; therefore, irrigation will be most influenced by the effects of climate change [22-31]. Different simulation models have been generated for climate change [32-34]. Most climate simulation models demonstrate global average temperature increases between 1.4 and $5.88^{\circ} \mathrm{C}$ by the end of this century, causing, among other things, an expected increase in sea levels [35]. Studies of the impact of climate change on the economy have also been conducted [36-40]. Developing countries are expected to be impacted by most effects caused by the climate crisis, while the richest countries are likely to be less affected by the impacts of these changes [41-43].

Based on different simulative mathematical models, several studies have been carried out to assess and predict the effects of climate change on farming, particularly the effects of climate change on irrigated production [44-46]. Irrigation in the agricultural sector is considered the largest consumer of freshwater for irrigated crop production. Therefore, irrigation will be the sector influenced the most by the effects of climate change. Using simulation models, the water consumption of various crops can be simulated, and thus, the water productivity of crops can be estimated. Estimating reference evapotranspiration becomes essential. Indeed, an adequate estimate of the reference evapotranspiration (Epot) is of primary importance in hydrological studies and in agricultural, watershed, and water resource management studies. Particularly, it is compulsory to run simulation models on climate change and to estimate the irrigation water requirements of crops, 
thereby supporting drought management and irrigation planning. The redefined Epot estimation methodologies of the Food and Agriculture Organization of the United Nations (FAO) have been efficaciously applied for different periods in many countries around the world [47,48]. Among the multitude equations proposed for the estimation of Epot, we cite that of Penman-Monteith (PM-Epot) [49-51]. This equation requires data on solar radiation or duration of sunshine, maximum and minimum temperatures, relative humidity, and wind speed.

It is expected that developing countries will be the countries most affected by the extent of climate change. Indeed, a large number of countries in Africa continue to face enormous challenges as they strive to meet the United Nations water-related Millennium Development Goals [52]. Additionally, water's fundamental role in achieving food security and in achieving the region's development goals is widely recognized. Furthermore, the scarcity of and demand for water and food security are closely linked to drought stress and climate change. As the balance between the demand and the availability of water has reached dangerous levels in many countries of the world, and increased water needs and food production are likely in the future, a sustainable approach to the control of water resources in agriculture is essential [53-56]. Nevertheless, there is an increased demand for water in West Africa. Therefore, water management difficulties and the future climate conditions under global climate change impacts are crucial issues associated with agricultural production in the Niger River basin [57].

Several studies have recently been performed on crop irrigation water requirements in the context of climate change in Africa [58-62]. Furthermore, in climate change scenarios, the availability of water resources decreases, and water shortages continue to challenge agricultural sustainability as well as other sectors sensitive to water scarcity. However, to date, no studies have been conducted simulating the effects of climate change on the irrigation water requirements of agricultural products; these products are most popular in countries of the Niger River basin and were analyzed in this study under different GCMs using the Smith's CROPWAT approach to calculate crop irrigation water requirements. The Penman-Monteith equation recommended by the FAO was used to calculate the potential evapotranspiration. The results of this study may help decision-makers in the countries of the Niger River basin plan future agricultural and irrigation strategies when facing the increasing problems of climate change. Therefore, the main objective of the current study was to provide an overview of the future impacts of climate change on the irrigation of agricultural products, such as rice, millet, maize, cassava, sorghum, and sugar cane, which are the foodstuffs most-consumed in countries of the Niger River basin. The study was conducted based on the intergovernmental panel on climate change (IPCC5) data through models such as CSIRO, ECHAM, and MIROC5. Additionally, two scenarios, specifically RCP 4.5 and RCP 8.5 , were chosen for each model.

\section{Materials and Methods}

\subsection{The Study Area}

The study area is the Niger River basin, which is located in the west of the African continent (Figure 1). The basin covers an area of 2,262,000 $\mathrm{km}^{2}$ between $5^{\circ} \mathrm{N}$ and $24^{\circ} \mathrm{N}$ latitude and $12^{\circ} \mathrm{W}$ and $17^{\circ} \mathrm{E}$ longitude; it is the fourth-largest basin in Africa after the Congo River Basin, the Nile River Basin, and the Lake Chad Basin. The Niger River basin is distributed over ten West African countries: Algeria, Benin, Burkina Faso, Cameroon, Ivory Coast, Guinea, Mali, Niger, Nigeria, and Chad. The northern part of the basin extends across the Sahara Desert in Algeria, and the hydrological networks in this desert area are inactive and completely depleted [9]. More than one hundred million people live near the river and are dependent on activities such as agriculture and extensive livestock farming. The Niger River is $4200 \mathrm{~km}$ long and is the third longest river in Africa after the Nile and the Congo. The Niger River rises in the mountains of Guinea at an altitude of approximately $800 \mathrm{~m}$ and passes through areas with diverse climatic characteristics [57]. However, much of the river water in the delta is lost due to evaporation and infiltration. The rainfall in 
the Niger River basin depends severely on the monsoon coming from the Atlantic. The monsoon extends from May to November. The Niger River basin extends over two climatic zones. The northern part of the basin is dominated by a semi-arid to arid climate; the south has a humid climate. The northern part of the basin is a desert zone, it has a rainfall of less than $400 \mathrm{~mm}$; the south has an annual rainfall of more than $4000 \mathrm{~mm}$ per year [63]. The temperature in the sub-equatorial zone (south of the basin) is around $24^{\circ} \mathrm{C}$; it is between 38 and $40{ }^{\circ} \mathrm{C}$ in the north of the basin (desert zone of the Sahara). The distribution of plants in the basin are heterogeneous [9]. However, according to FAO data, agricultural products vary from country to country. However, depending on the climatic zones, the cereals tend to be cultivated in the north of the basin, while in the south, it is instead the tubers that are cultivated the most. Moreover the agricultural seasons are very variable according to the countries.

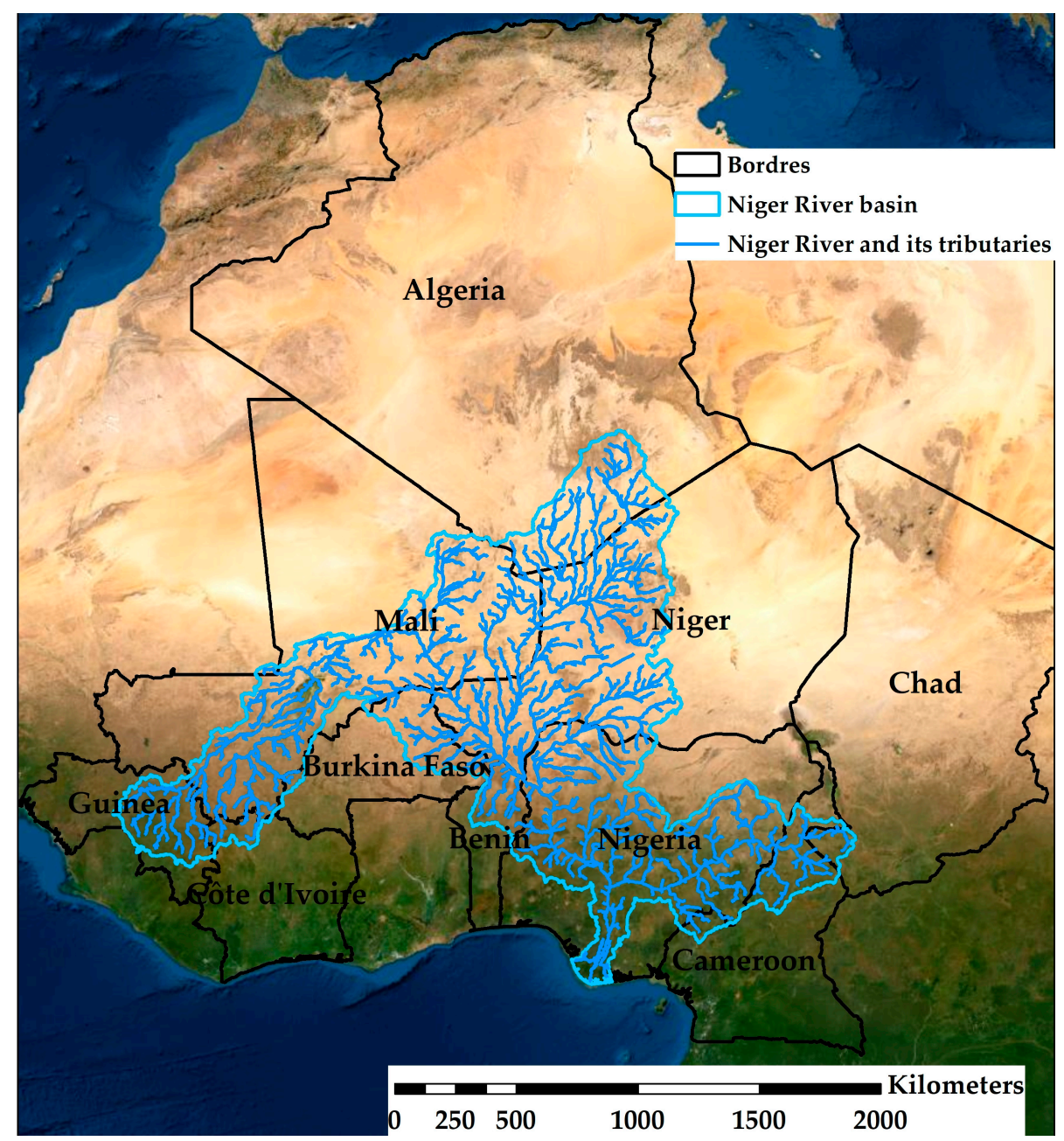

Figure 1. Map of the Niger River basin. The map shows the ten countries in the basin and the river's tributaries. The map was constructed on a satellite image from the ESRI (Environmental Systems Research Institute) base map.

\subsection{Data Source}

The IPCC 5 database (http:/ / www.ipcc-data.org/sim/gcm_global/index.html, accessed on 20 December 2019) provided us with data on climatic conditions. The precipitation and temperature data were used. Sixty (60) years were chosen for the temporary aspect, from 2020 to 2080. The highest and the lowest irrigation water requirements was selected to observe the inter-annual variation of each GCM. Three GCMs (CSIRO, MIROC5, and ECHAM. MPI-ESM-LR) were used as future climate change scenarios. Moreover, 
two representative concentration pathways (RCP 4.5 and RCP 8.5) were chosen for each model. In our agro-climatological approach, six crops were selected, and it was assumed that these crops were planted under optimal conditions for their growth. These plants are among the most commonly used plants in the diets of populations in the basin. Any changes in the flooded areas' location and dimension due to adaptation to climate change or any other cause have been overlooked. Increasing the concentration of $\mathrm{CO}_{2}$ in the atmosphere improves photosynthesis in plants and reduces water consumption of crops. Delphine Deryng et al. [64] demonstrated the beneficial role of the effect of increasing $\mathrm{CO}_{2}$ concentration on agricultural production and water consumption. Hence, due to insufficient quantitative knowledge of the increase in $\mathrm{CO}_{2}$ and its direct effects on crops, its effects have also been ignored.

\subsection{The Net Irrigation Water Requirement Model}

The net irrigation water requirement was calculated using Smith's CROPWAT approach [65]. The principle of this model is the variance between the effective precipitation and the crop-specific potential evapotranspiration, calculated as:

$$
I W R=K c \cdot E T o-\text { Peff if Kc.ETo }>\text { Pef; otherwise IRnet }=0
$$

where IWR is the net irrigation water requirement, used instead of the net irrigation water requirement per unit area $[\mathrm{mm} / \mathrm{d}] ; P_{\text {eff }}$ is the effective precipitation $[\mathrm{mm} / \mathrm{d}] ; E T o$ is the reference evapotranspiration $[\mathrm{mm} / \mathrm{d}]$; and $K_{c}$ is the crop coefficient. The need for irrigation may be underestimated or overestimated, because it is not linear with respect to rainfall and potential evapotranspiration. On a global average, the underestimation is only $2.4 \%$, but it can be significant in areas with low net irrigation needs [66].

The crop type and the day of the growing period determine the crop coefficient $\left(K_{c}\right)$. However, in this study, the mid-season stage $\left(\mathrm{K}_{\mathrm{c} \text { mid }}\right)$ is used. The mid-season stage is the stage in which a crop needs the most water for its optimal development. The selection of the $\mathrm{K}_{\mathrm{c} \text { mid }}$ will allow the evaluation of the IWR with a large margin. The $P_{\text {eff }}$ is the fraction of total precipitation $(P)$ that is directly accessible to crops and does not leave the area as runoff. Several factors influence the variation of the $P_{\text {eff. }}$. The characteristics of precipitation, soil properties, crop evapotranspiration rates and irrigation management are the main factors. However, the soil characteristics are the parameters whose data are not taken into account in the $P_{\text {eff }}$ calculations. Absorption and retention properties, and the release and movement of water greatly influence efficiency of precipitation. The $P_{\text {eff }}$ is very difficult to determine; however, the soil conservation method of the United States Department of Agriculture (USDA) is used to select the $P_{\text {eff }}$ through the following formulas:

$$
\begin{gathered}
P_{\text {eff }}=\frac{P(4.17-0.2 P)}{4.17} \text { for } P<8.2 \\
P_{\text {eff }}=4.17+0.1 P \text { for } P \geq 8.2
\end{gathered}
$$

In this study, the modified Penman-Monteith method was used. This method is recommended by $\mathrm{FAO}$, and is widely recognized as being efficient and effective for estimating evapotranspiration [67].

$$
E T o=\frac{0.408 \Delta\left(R_{n}-G\right)+\gamma\left(\frac{900}{T+273}\right) u_{2}\left(e_{s}-e_{a}\right)}{\Delta+\gamma\left(1+0.34 u_{2}\right)}
$$

where $\Delta\left(\mathrm{kPa} /{ }^{\circ} \mathrm{C}\right)$ is the slope vapor pressure curve; $R_{n}\left(\mathrm{MJ} / \mathrm{m}^{2} \cdot \mathrm{d}\right)$ is the net radiation; $\mathrm{G}$ $\left(\mathrm{MJ} / \mathrm{m}^{2} \cdot \mathrm{d}\right)$ is the soil heat flux and generally can be ignored at daily time-steps; $\gamma\left(\mathrm{kPa} /{ }^{\circ} \mathrm{C}\right)$ is the psychrometric constant; $u_{2}(\mathrm{~m} / \mathrm{s})$ is the daily mean wind speed at $2 \mathrm{~m}$ height; $e_{S}(\mathrm{kPa})$ is the saturation vapor pressure; and $e_{a}(\mathrm{kPa})$ is the daily mean actual vapor pressure. 


\subsection{Climate Input}

For each model, the temperature and precipitation data are converted into the units of the different formulas after calculation of all the parameters according to the previous equations with the climate data operation (CDO) in Ubuntu. Ubuntu is an open-source operating system in the Linux system. Each climate data point is remapped before being used in the $\mathrm{CDO}$, this process allows putting all the data in the same resolution. Each model's results are input to ArcGIS, in which the statistical distribution of the IWR of each crop is determined in each country of the Niger basin.

\section{Results}

In this long-term IWR study, the different climatic models used show different amounts of IWRs. These quantities represent the total average amount of water that each country should use each year for each crop's optimal development.

\subsection{Irrigation Water Requirement according to CSIRO}

\subsubsection{RCP 4.5}

Figure 2 shows the distribution of the total IWR over the entire Niger basin. We note that Mali, Niger, and Burkina-Faso have a total IWR of about $45 \mathrm{~mm} /$ day. Nigeria, Guinea, Ivory Coast, Cameroon, and Chad have a total IWR of less than $30 \mathrm{~mm} /$ day.

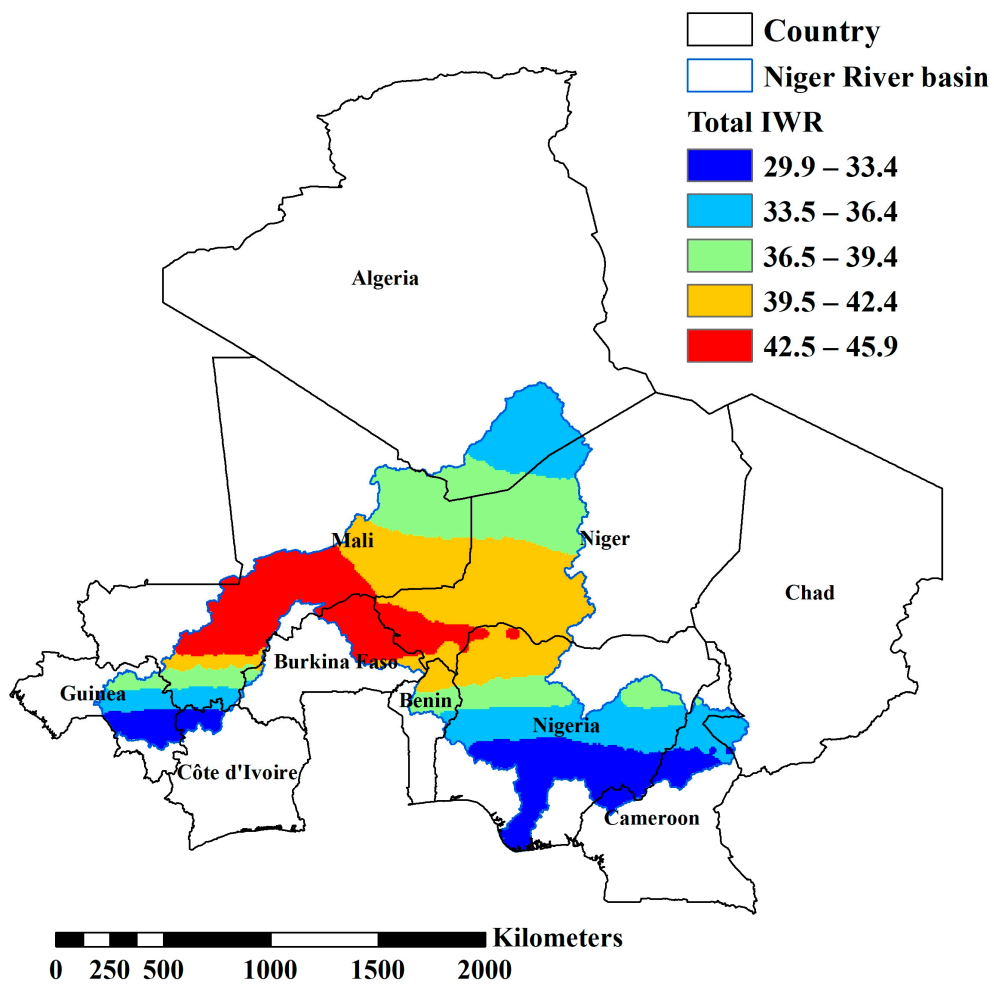

Figure 2. IRW under CSIRO. It shows the global irrigation water requirements in different countries in the basin under the RCP 4.5 .

Figure 3A shows the annual change in the IWR from 2020 to 2080. The year 2027 is projected to be the year with the smallest annual amount of IWR for all crops. The model results for 2079, projected that 2079 will be the year with the highest amount of IWR. The inter-annual results of the two years are presented in Figure 3B,C. We observe in Figure 3B that the months from January to March are the months with the highest amount of IWR. However, low quantities are observed from May to October, then an increase is observed in December. Figure $3 C$ shows an increase between January and March with a peak in March, and then we will see a decrease in June, then an increase from July to December. 

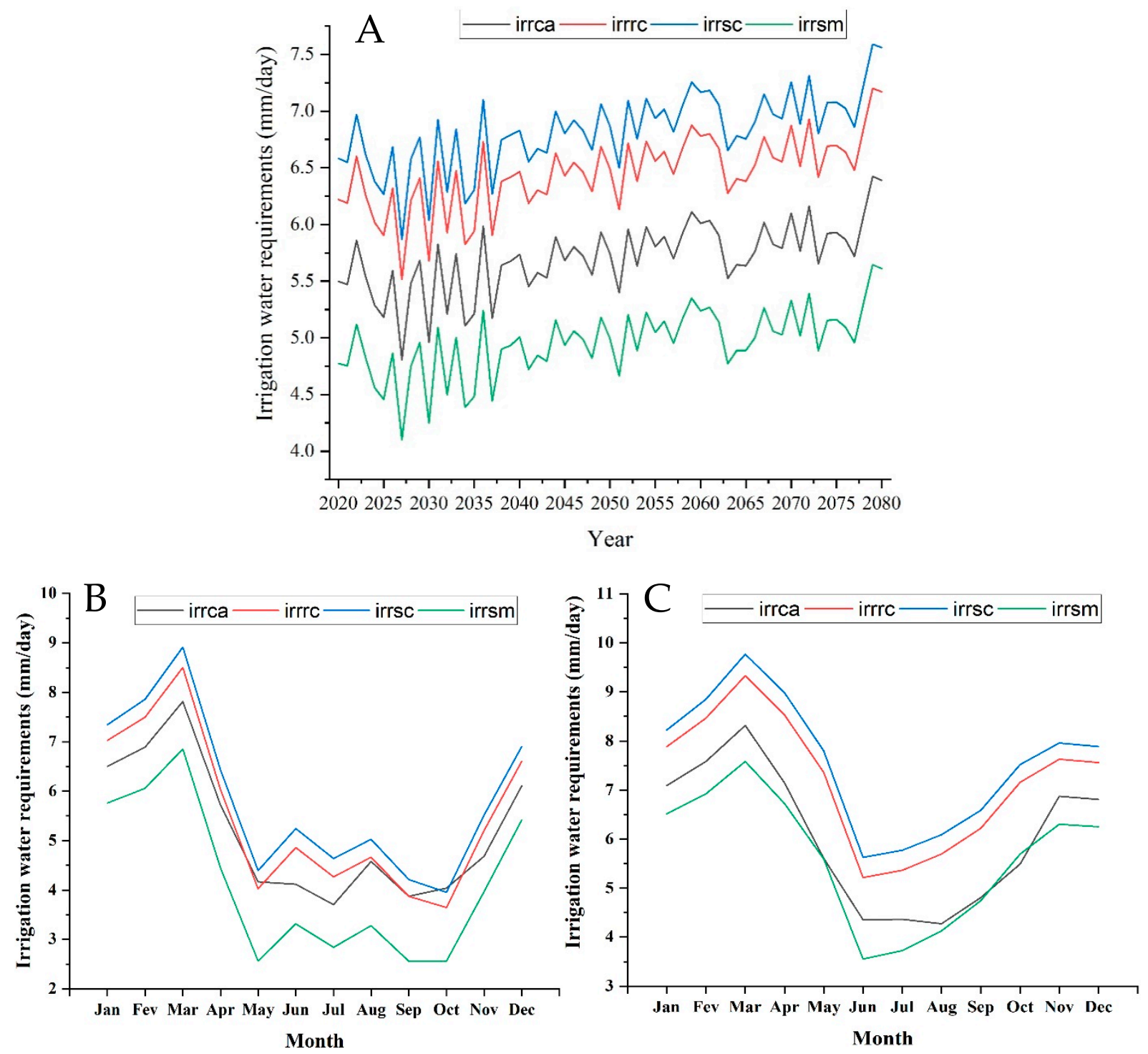

Figure 3. Evolution of irrigation water requirements (IWR) in mm/day under CSIRO RCP 4.5. (A) Demonstrates annual irrigation water requirements. (B) Demonstrates monthly irrigation water requirements for 2027, with the lowest irrigation water requirements by crops. (C) Demonstrates monthly irrigation water requirements for 2079, with the highest irrigation water requirements by crops. irrca denotes irrigation water requirement of cassava; irrrc denotes irrigation water requirement of rice and corn; irrsc denotes irrigation water requirement sugar cane; irrsm denotes irrigation water requirement of sorghum and millet. Jan means January; Feb means February; Mar means March; Apr means April; Jun means June; Jul meas July; Aug means August; Sep means September; Oct means October; Nov means November; Dec means December.

The inter-annual results of the two years are presented in Figure 3B,C. We observe in Figure $3 \mathrm{~B}$ that the months from January to March are the months with the highest amount of IWR. However, low quantities are observed from May to October, then an increase is observed in December. Figure 3C shows an increase between January and March with a peak in March, and then we will see a decrease in June, then an increase from July to December.

\subsubsection{RCP 8.5}

For the RCP 8.5, the yearly IWR (Figure 4.) shows a lower IWR than the RCP 4.5. However, only three countries (Guinea, Nigeria, and Cameroon) have low IWR. The other countries (Mali, Niger, Burkina-Faso, Benin, and north of Nigeria) have an IWR of more than $23 \mathrm{~mm} /$ day. Mali has the highest total IWR. 


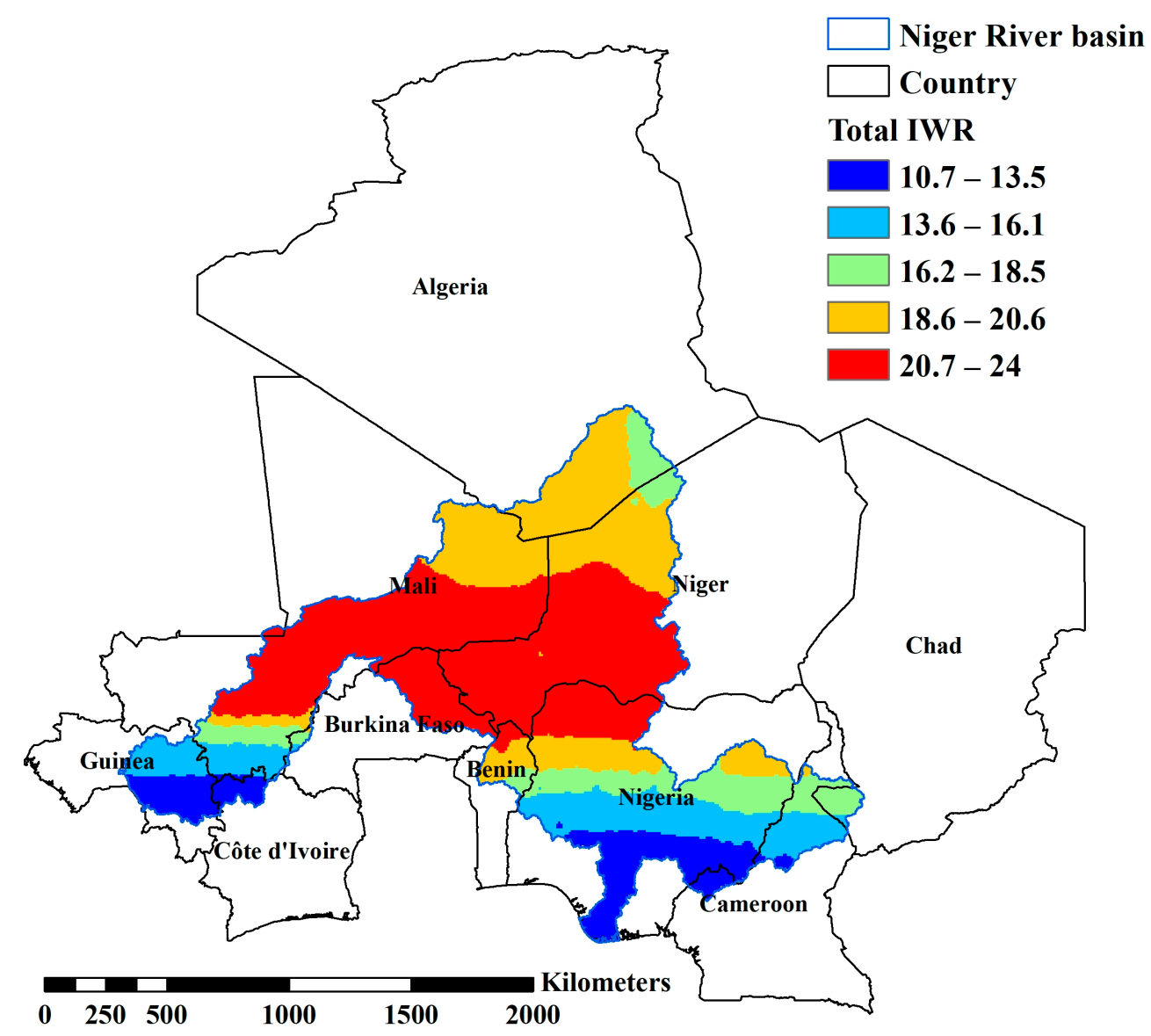

Figure 4. IRW under CSIRO. It shows the global irrigation water requirements in different countries in the basin under the RCP 8.5 .

According to RCP 8.5 the IWR will increase from 2020 to 2080. The Figure 5A shows the evolution of the IWR during the next sixty years. However, two specific years can be observed. The result shows that the year 2029 represents the year with the lowest IWR, and the year 2080 with the highest IWR. Figure 5B shows the inter-annual evolution of the lowest year (2029), which indicates the months of January to March as the periods of high water demand (IWR). The low IWR is between May and September. July is the lowest month of the year. In October, the IWR will observe an increase until December. In 2080 (Figure 5C), the year when the IWR will reach the highest quantities, the IWR will exhibit much the same phenomenon as 2029. However, the low quantities of IWR will be observed in May and August. The increase will start in September.

\subsection{Irrigation Water Requirement according to ECHAM}

\subsubsection{RCP 4.5}

The RCP 4.5 scenario modeled with ECHAM presents results very different from those of CSIRO. Indeed, the extreme north of the Niger River basin will record the highest IWR (Figure 6), over $22 \mathrm{~mm}$ /day. The southern part of the basin will present IWR around $11 \mathrm{~mm} /$ day. Guinea, Ivory Coast, and southwestern Mali are the areas with the lowest IWR quantities, less than $9 \mathrm{~mm} /$ day. 

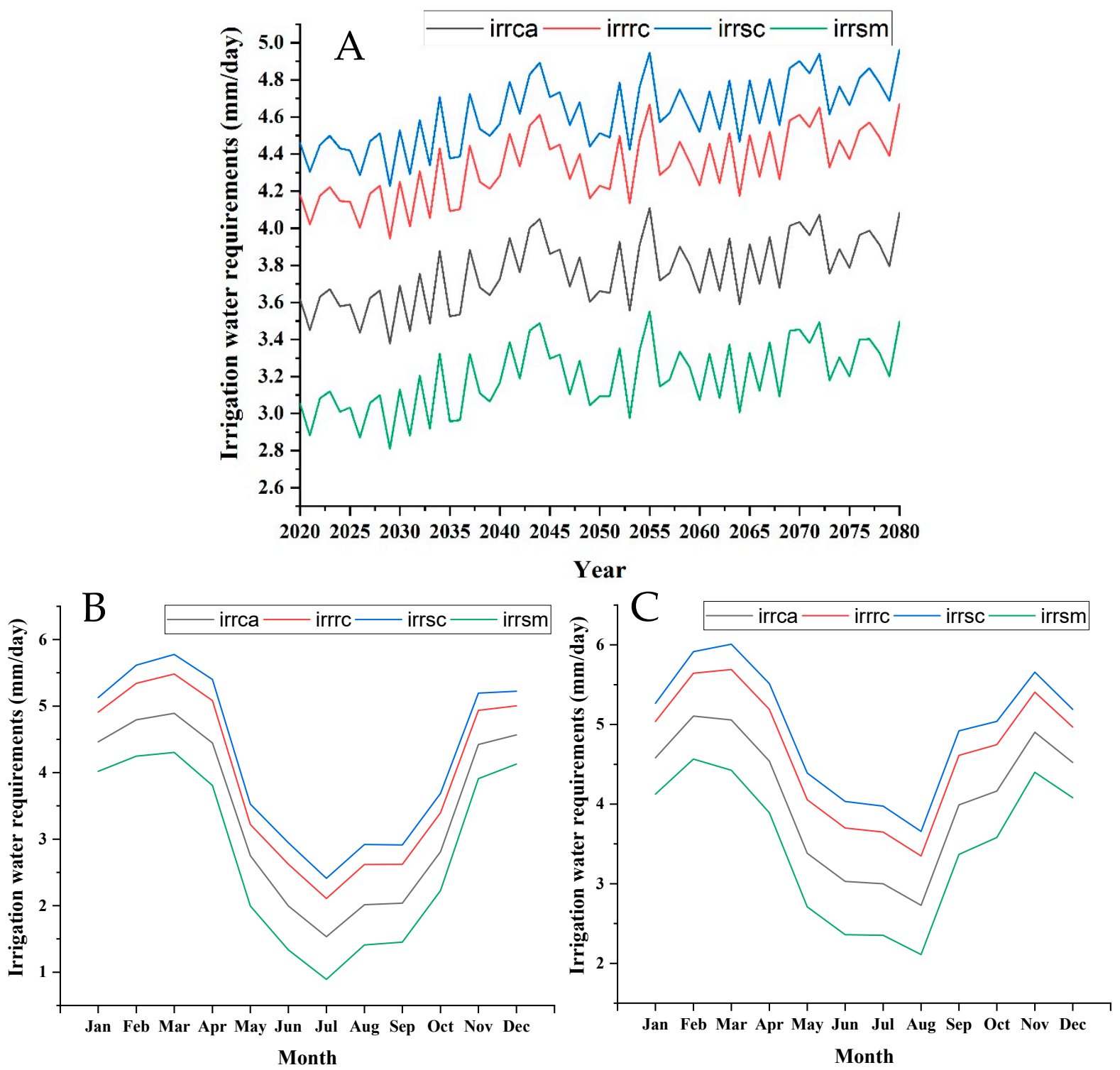

Figure 5. Evolution of IWR (in mm/day) under CSIRO RCP 8.5. (A) Demonstrates annual irrigation water requirements. (B) Demonstrates monthly irrigation water requirements for 2027, with the lowest irrigation water requirements by crops. (C) Demonstrates monthly irrigation water requirements for 2079, with the highest irrigation water requirements by crops. Same as Figure 3.

The IWR varies enormously from year to year. Figure 7A shows this irrigation variation of the IWR over the next 60 years. However, two years are to be noted-the year 2041 is projected to be the year which will record the lowest quantity of IWR in the Niger River basin, and the results also predicted that the year 2063 will present the highest quantity of IWR. The inter-annual IWR in 2041 (Figure 7B) will present the largest quantities of IWR from January to March, with a peak in February. However, this quantity will decrease between July and September; August will be the month during which the IWR will be the lowest. In 2063 (Figure 7C), the IWR will high from January to March (with the highest IWR). Therefore, the IWR will decrease between August and September, and then it will increase until December. 


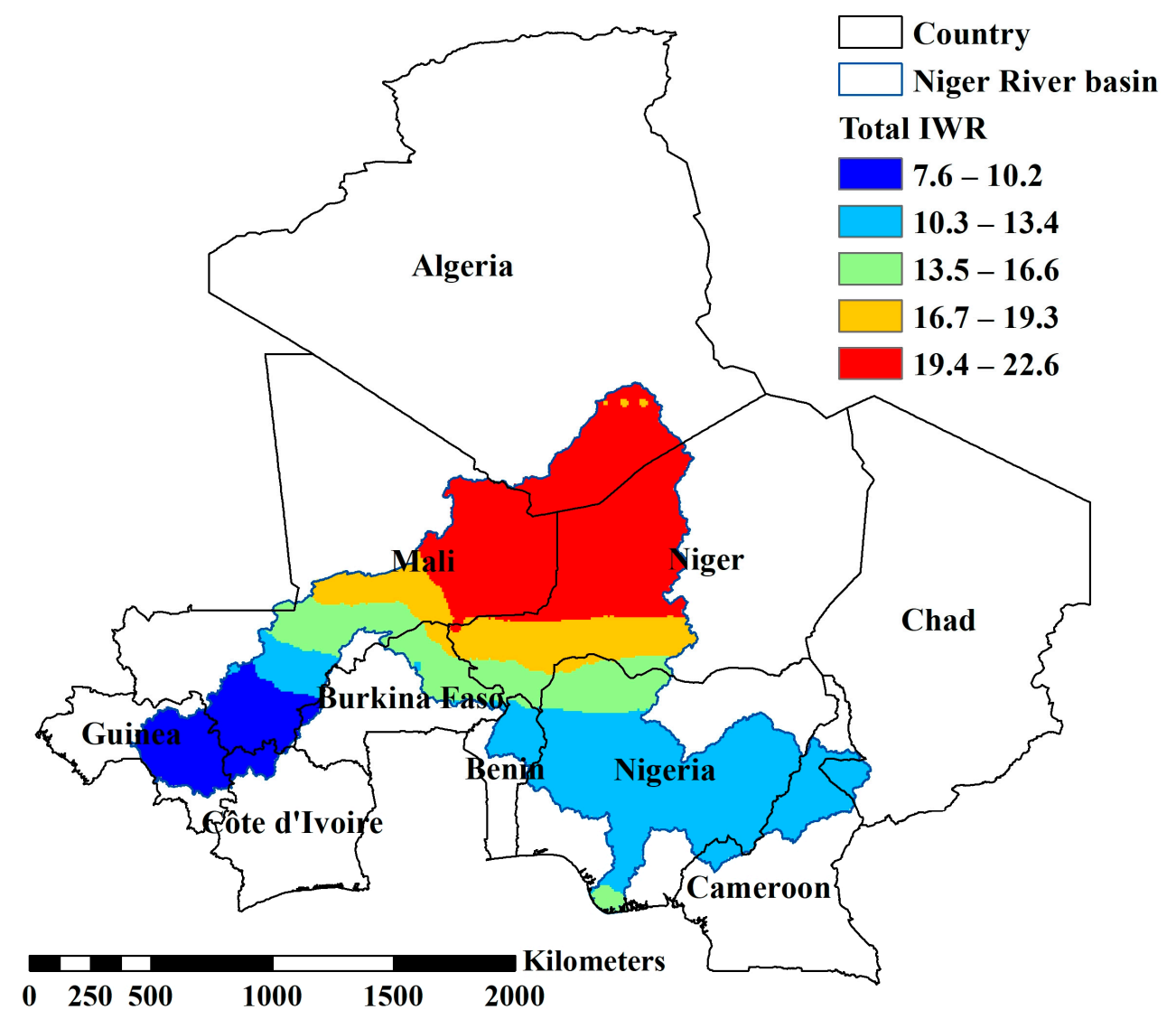

Figure 6. IRW under ECHAM. It shows the global irrigation water requirements in different countries in the basin under the RCP 4.5 .

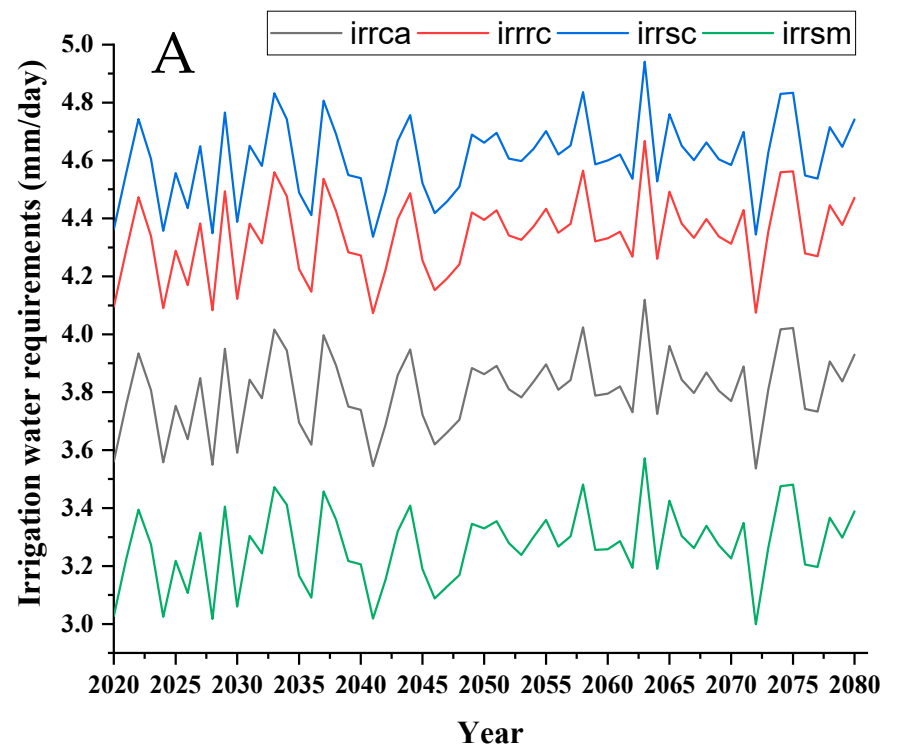

Figure 7. Cont. 

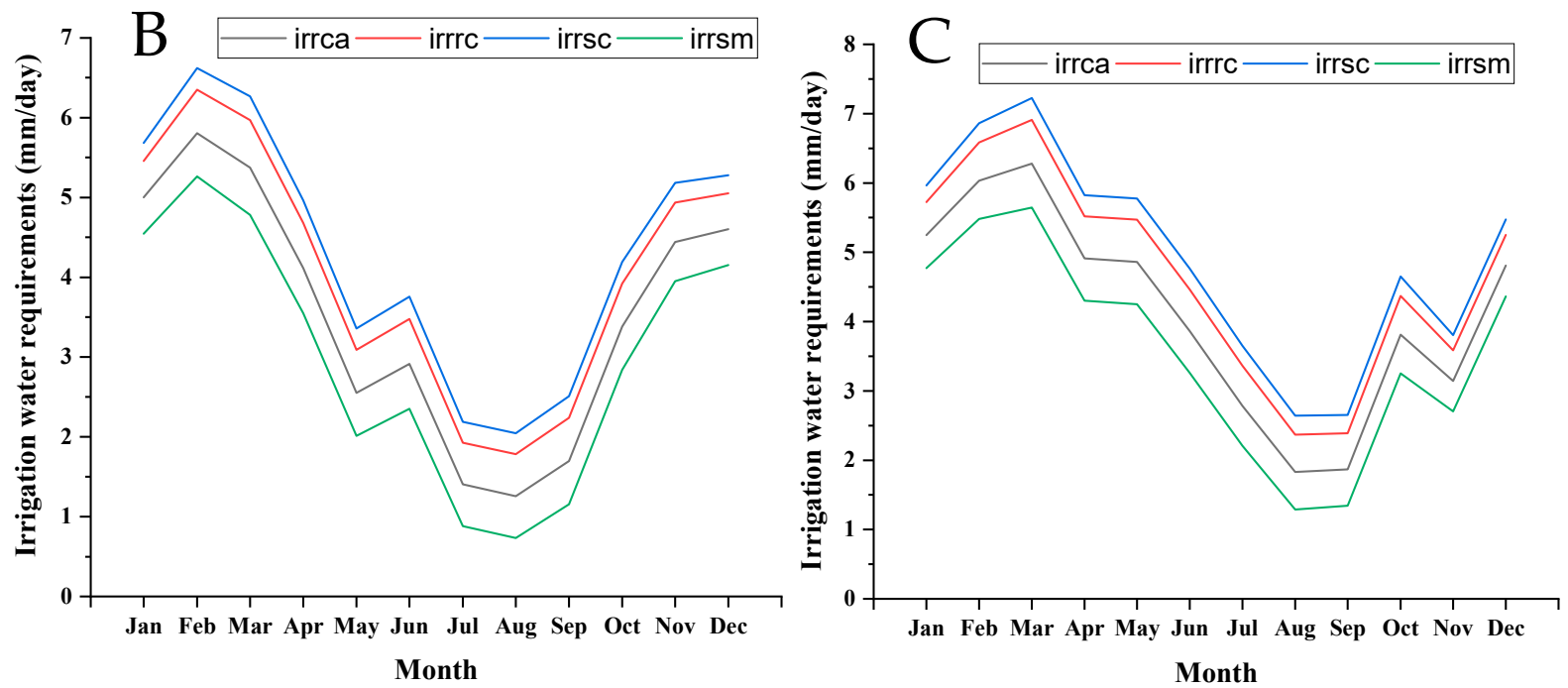

Figure 7. Evolution of IWR (in mm/day) under ECHAM RCP 4.5. (A) Demonstrates annual irrigation water requirements. (B) Demonstrates monthly irrigation water requirements for 2041 with the lowest irrigation water requirements by crops. (C) Demonstrates monthly irrigation water requirements for 2063, with the highest irrigation water requirements by crops. Same as Figure 3.

\subsubsection{RCP 8.5}

The RCP 8.5 (Figure 8) presents the same distribution shown by RCP 4.5. The same distribution is shown by RCP 4.5. However, the IWR amounts between the two scenarios (RCP 4.5 and RCP 8.5) are different.

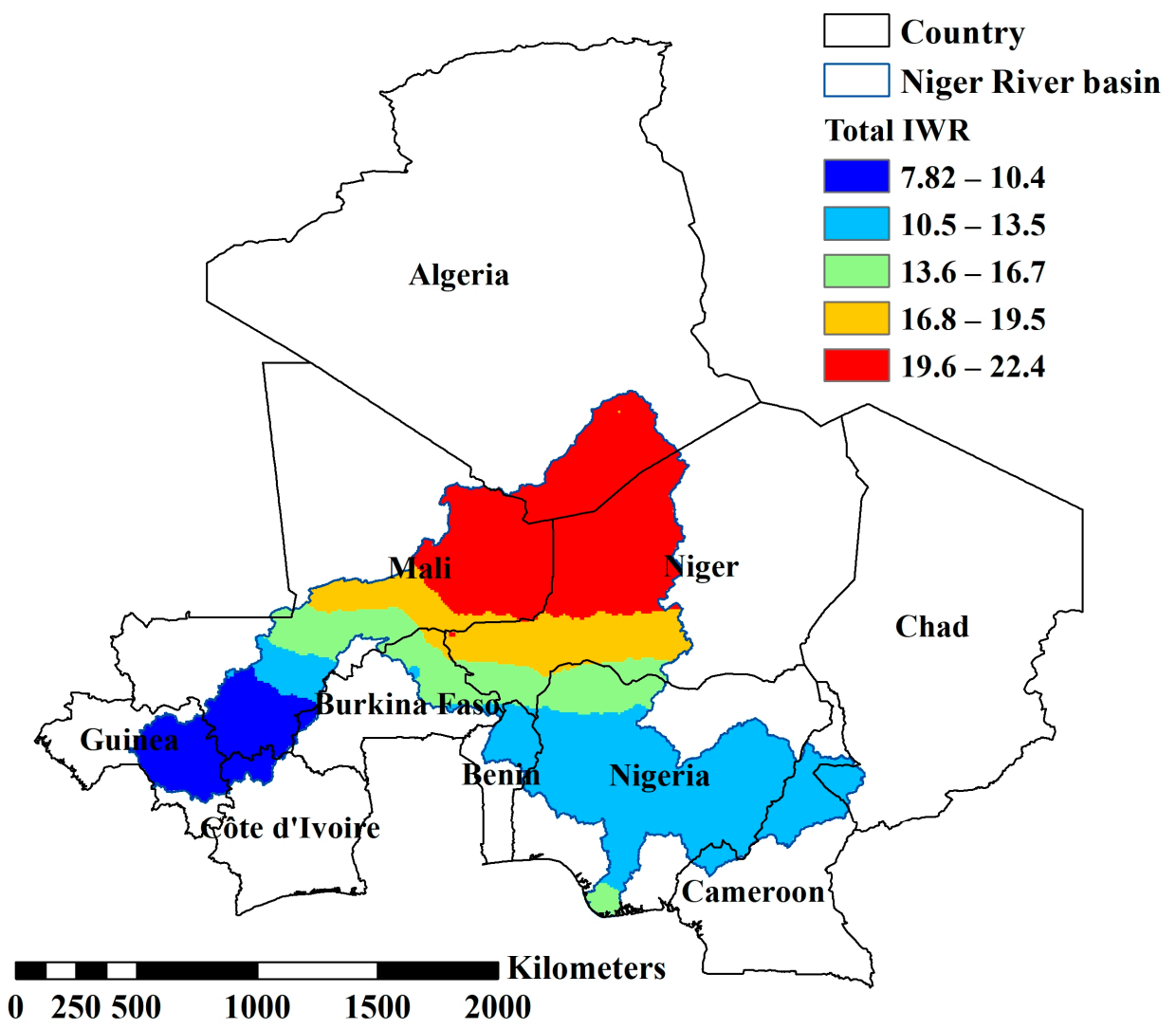

Figure 8. IRW under ECHAM. It shows the global irrigation water requirements in different countries in the basin under the RCP 8.5 . 
Significant variations in the IWR will be observed in the Niger River basin over the next 60 years. However, the variations will be less pronounced between 2045 and 2060. Figure 9A makes it possible to identify two specific years, the year 2037 (this year is estimated to be when IWR is the lowest) and the year 2043 (the year at the heart of which the IWR is the highest). Figure $9 B, C$, respectively, illustrate the monthly variation of these two specific years. The months of January to March are periods where irrigation is important. However, the peak is observed in February 2037, whereas it will be detected in March 2043. IWR quantities are lower between May and October, with a peak observed in August 2037 and July 2043. Then the IWR will increase again until December.
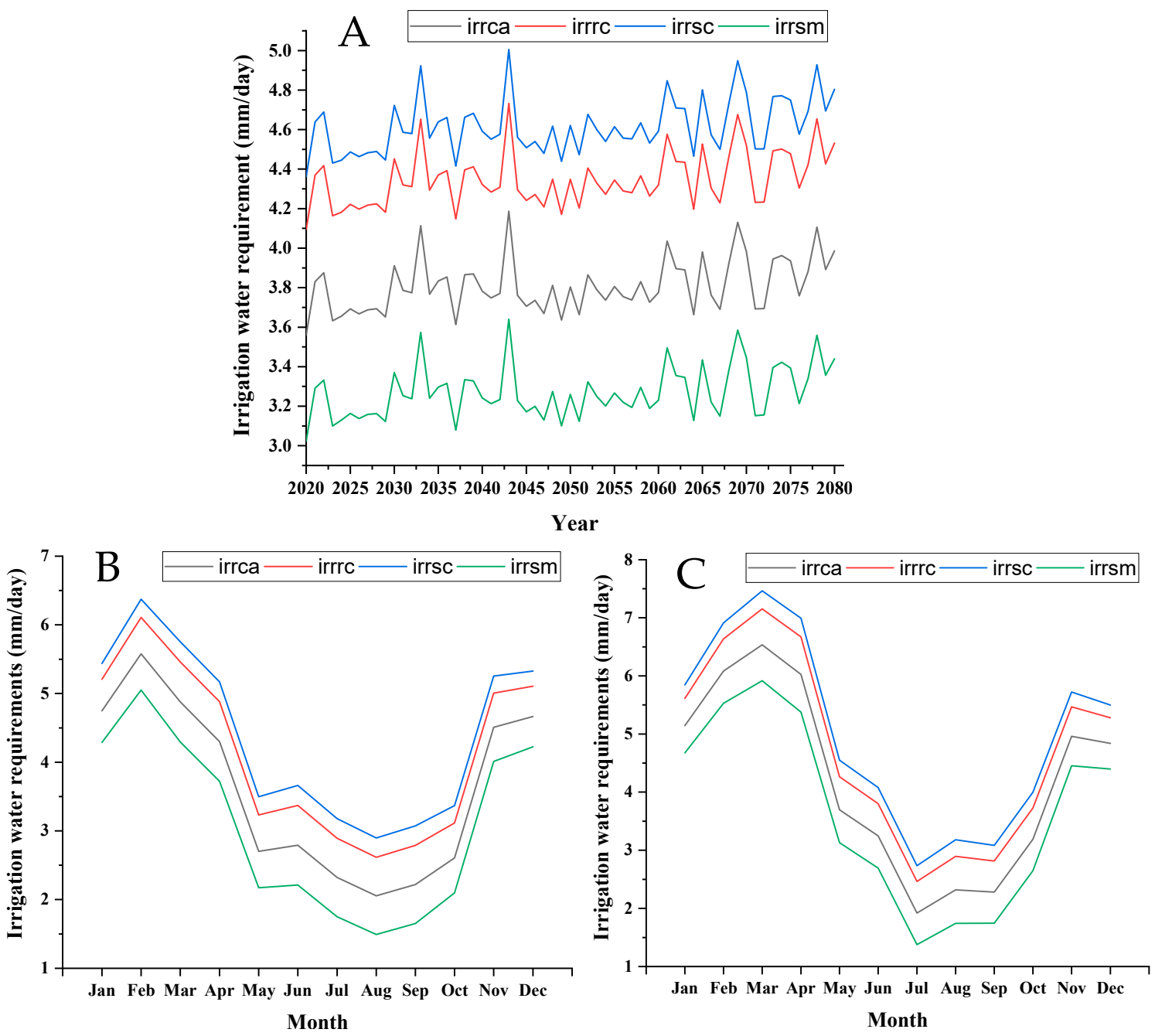

Figure 9. Evolution of IWR (in mm/day) under ECHAM RCP 8.5. (A) Demonstrates annual irrigation water requirements. (B) Demonstrates monthly irrigation water requirements for 2037, with the lowest irrigation water requirements by crops. (C) Demonstrates monthly irrigation water requirements for 2043 with the highest irrigation water requirements by crops. Same as Figure 3.

\subsection{Irrigation Water Requirement according to MIROC 5}

\subsubsection{RCP 4.5}

The RCP 4.5 (Figure 10) shows the distribution of the IWR within the basin. According to RCP 4.5, the countries (Algeria, Mali, Niger, and Burkina Faso) in the north of the basin will have the highest quantities of IWR in the basin. However, the other countries have an IWR of less than $9 \mathrm{~mm} /$ day. 


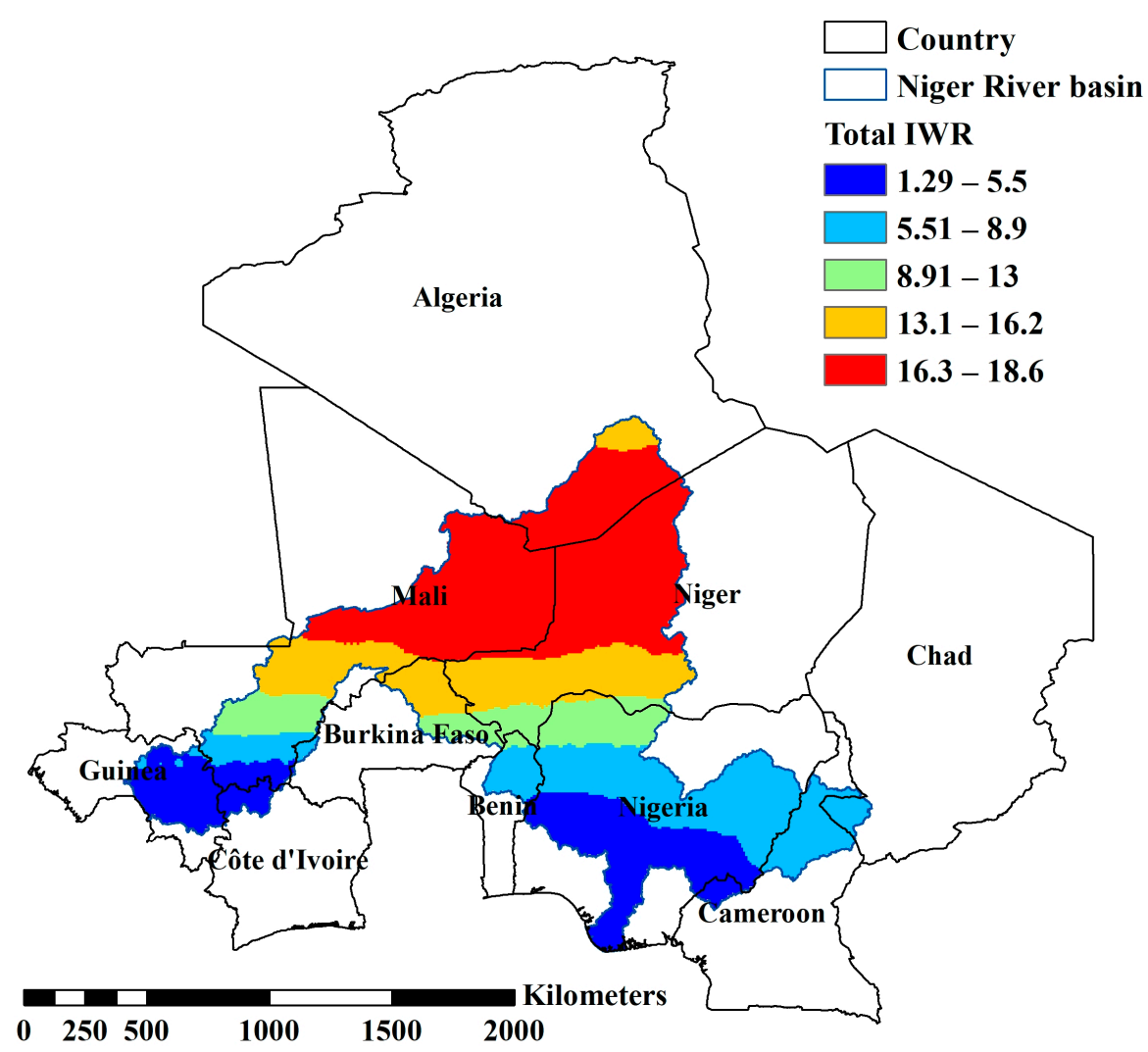

Figure 10. IRW under MIROC 5. It shows the global irrigation water requirements in different countries in the basin under the RCP 4.5 .

Figure 11A shows the evolution of the IWR over the next 60 years between 2020 and 2080. However, 2023 is the year predicted to have the lowest amount of IWR, and the year 2043 is the year with the largest amount of IWR. The monthly variations of these two specific years are illustrated respectively in Figure 11B,C. In 2023, the IWR will be at its maximum in January and February and at its minimum in August and September. In 2043, the highest values of IWR will be observed between January and March, with a peak in March. The lowest values will be observed in July then in September, the IWR will increase thereafter until December.

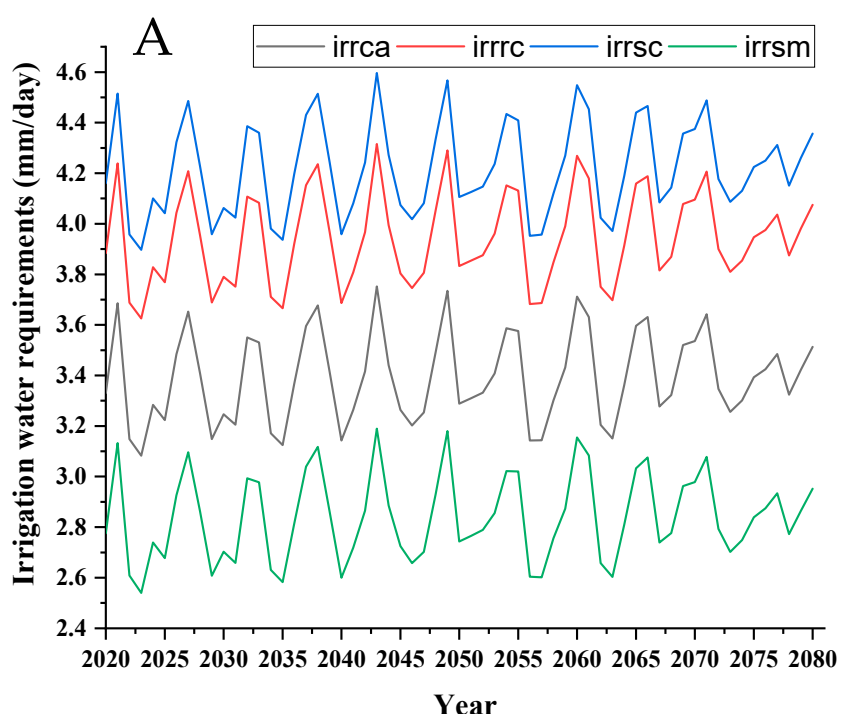

Figure 11. Cont. 

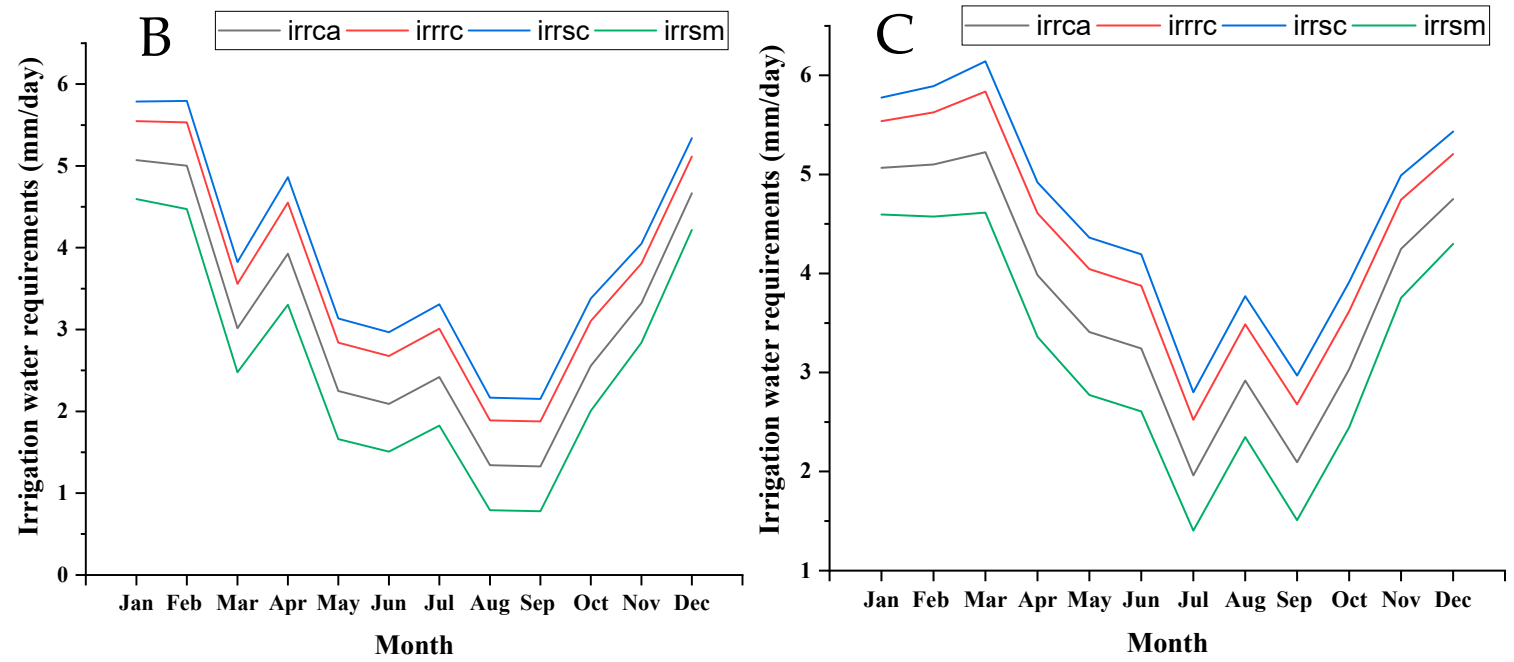

Figure 11. Evolution of IWR (in mm/day) under MIROC 5 RCP 4.5. (A) Demonstrates annual irrigation water requirements. (B) Demonstrates monthly irrigation water requirements for 2023, which have the lowest irrigation water requirements by crops. (C) Demonstrates = monthly irrigation water requirements for 2043 with the highest irrigation water requirements by crops. Same as Figure 3.

\subsubsection{RCP 8.5}

The distribution of IWR in the Niger basin is similar to that indicated by RCP 4.5; however, the IWR quantities of RCP 8.5 are higher (Figure 12). Quantities vary from $2.4 \mathrm{~mm} /$ day to over $20 \mathrm{~mm} /$ day.

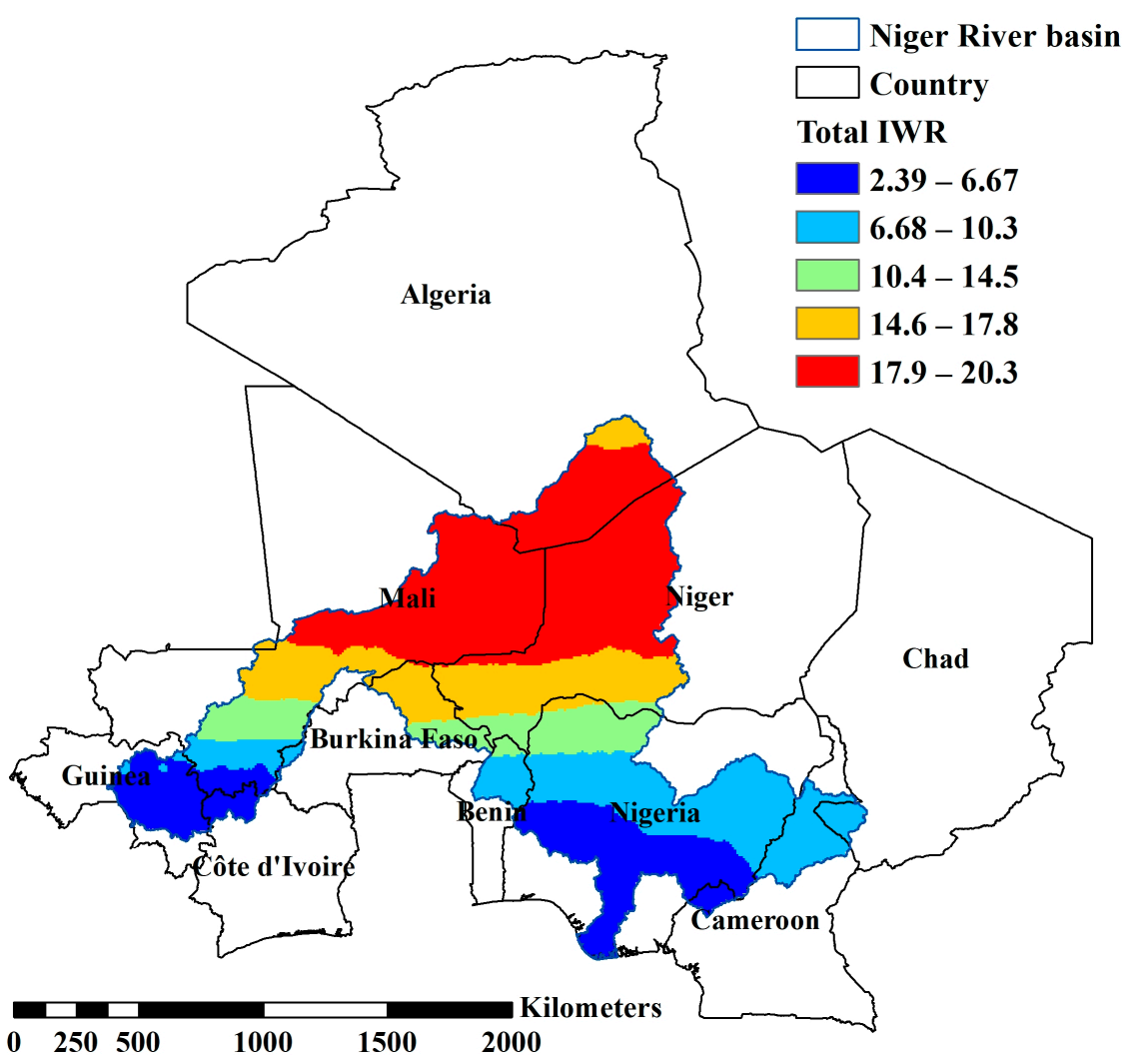

Figure 12. IRW under MIROC 5. It shows the global irrigation water requirements in different countries in the basin under the RCP 8.5. 
Figure 13A shows the evolution of the IWR between 2020 and 2080. There are thus two specific years-according to the results 2030 is the year in which the IWR is at its lowest, and 2066 is the year in which the IWR is the highest of the 60 years. Figure 13B presents the annual evolution of the IWR in 2030; January to March are the highest with a peak in February. The lowest IWR quantities will be observed in July to October with a peak in August. In 2066 (Figure 13C), the IWR will be at its maximum with a peak in February. However, the IWR will be at its minimum between June and October with a peak in July and September.
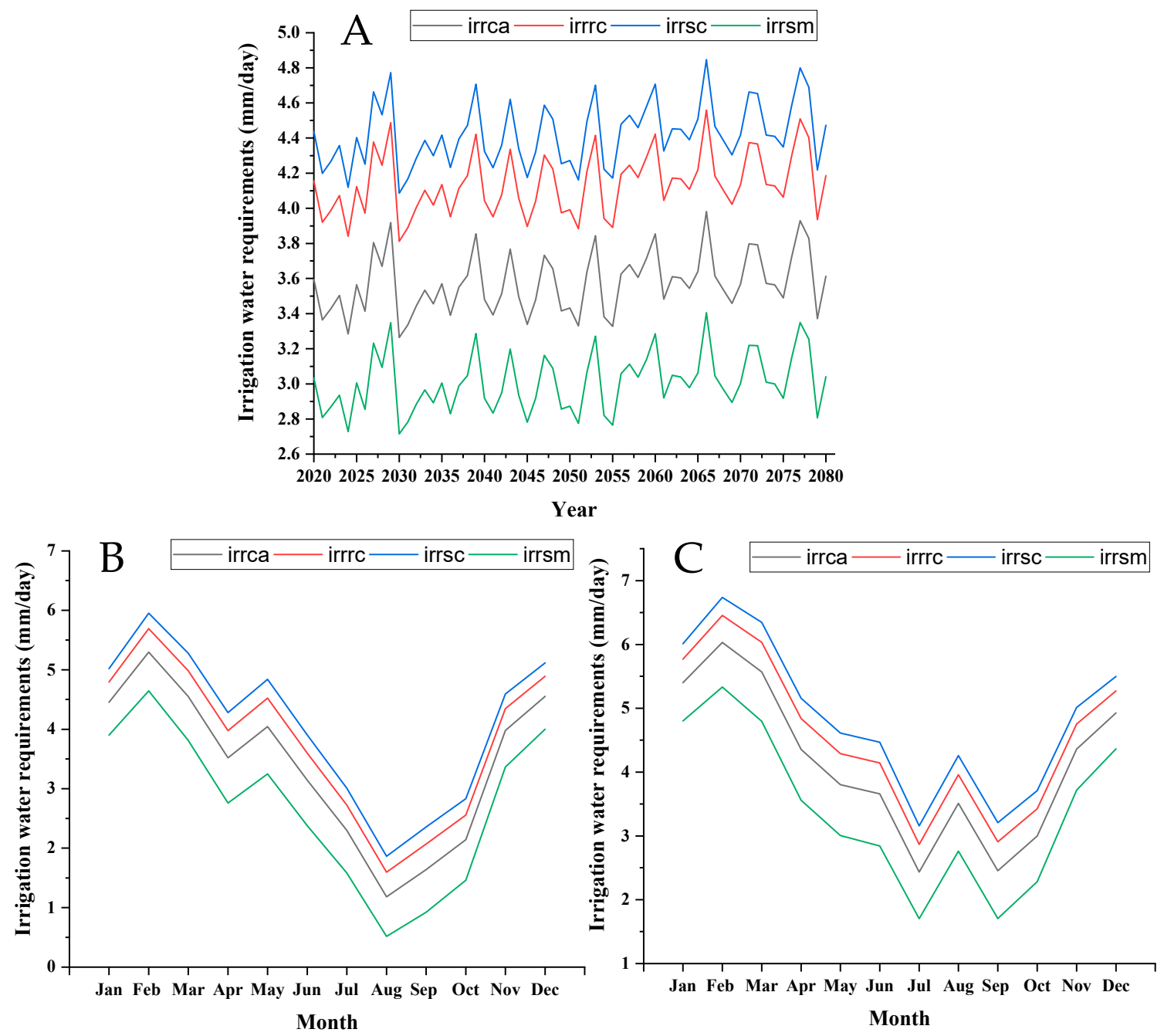

Figure 13. Evolution of IWR (in mm/day) under MIROC 5 RCP 8.5. (A) Demonstrates annual irrigation water requirements. (B) Demonstrates monthly irrigation water requirements for 2030, with the lowest irrigation water requirements by crops. (C) Demonstrates monthly irrigation water requirements for 2066, with the highest irrigation water requirements by crops. Same as Figure 3.

\section{Discussion}

Studies on climate projections always present some degree of uncertainty. Therefore a discussion of the different sources of uncertainty isrequired.

The simulation of the same greenhouse gas emission scenario by different GCMs, gives different climate change scenarios [22,68-70]. This is the example of the CSIRO RCP 4.5 in this study, which predicts an IWR of about double the other models. There is also non-consideration of the effects of $\mathrm{CO}_{2}$ concentration, GCMS, on plants eventually underestimated regional warming and overestimation of humidity, especially in tropical areas $[22,66]$. The other source of uncertainty is relative to the lack of knowledge about 
irrigated crops in this sub-Saharan part of Africa; providing simplistic modeling of the irrigation model, causing uncertainty in the evaluation of current irrigation requirements and the assessment of impacts on climate change.

In the same perspective, Ed Hawkins and Rowan Sutton [68] explain that uncertainties in climate prediction come from three different sources. First, the climate system's internal variation, which is the consequence of natural fluctuations without any radiative strength of the planet. Second, the response uncertainty, indeed, from the climate system's natural fluctuation, the different models propose different climate change. Furthermore, uncertainty about the future greenhouse gas emissions will also impact climate prediction.

Thus, during the interpretation of the results, our results, limits, and corresponding uncertainties must be kept in mind.

According to the IPCC 5, whose database was used in this study, the whole world will experience an increase in temperature and precipitation in the coming years [71]. However, Africa will face a significant climatic upheaval as well as a rainfall deficit, which will have direct consequences on crop productivity [72]. This situation is more accentuated in sub-Saharan Africa than in other regions, as sub-Saharan Africa is projected to most often face a significant rainfall deficit [73].

According to FAOSTAT data (http:/ / www.fao.org/faostat/en/\#data/QC, accessed on 12 May 2020), the countries in the Niger River basin have experienced an increase in the production of certain crops. Thus, Nigeria is the leading cassava producer, with more than 59 million tons grown each year between 2015 and 2018. Nigeria is also the top producer of maize, with more than 10 million tons produced each year between 2015 and 2018. The top producer of rice, with an average production of approximately 6.7 million tons between 2015 and 2018. Nigeria also dominates sorghum production, although the production of sorghum experienced a decrease in Nigeria in 2018. Niger is the leading producer of millet. The millet production of Niger rose from 3.4 million tons in 2015 to more than 3.8 million tons in 2018, according to FAOSTAT. Ivory Coast dominates the production of sugar cane, but the annual production of sugar cane has decreased, and, in effect, its production thus fell from 2 million tons in 2015 to approximately 1.9 million tons in 2018.

The Niger River basin covers two types of climate. In the north, the climate is essentially arid or semi-arid; these climates generally extend over Mali, Algeria, and Niger. In the south, the climate is generally humid; it extends over Guinea, Ivory Coast, Nigeria, Cameroon, and Chad. The inter-annual results of the IWR, according to the set of models selected, illustrate that the largest quantities of water used for irrigation are generally observed between January and March, and the lowest quantities are the most often seen between July and September. The rainy season generally begins in May and June in the great majority of countries located in the arid or semi-arid zone, and this season lasts three to five months. Therefore, the amount of IWR is lower for all the crops selected in the basin. Between September and October, the models predict the start of the increase in the IWR; this is explained by the end of the rainy season over a large part of the basin's countries.

The majority of models also illustrate a peak in the IWR between March and April; in fact, it corresponds to the excessive heatwave in almost all the countries of the basin. The heatwave is important in countries located in arid and semi-arid zones such as Niger, Mali, or Algeria. The amount of water used in irrigation varies from year to year; however, the IWR also varies by country. In Tables 1-3, the variation of the IWR of different plants in different basin countries is shown in the evidence. Therefore, countries in the arid and semi-arid zone will use more irrigation. Countries such as Algeria, Mali, Niger, and Burkina-Faso are the most affected by the use of large amounts of IWR. Countries south of the basin will have the lowest amounts of IWR in the basin due to a long rainy season compared to countries in arid and semi-arid zones. Indeed, the zone comprising the extreme south of Algeria, the northwest of Niger, and the northeast of Mali is hydraulically inactive; this also favors the Sahara Desert's advancement. 
Table 1. Total irrigation water requirements (IRW) in mm/day under CSIRO.

\begin{tabular}{|c|c|c|c|c|c|c|c|c|}
\hline \multirow{3}{*}{ Country } & \multicolumn{8}{|c|}{ Year 2020-2040 } \\
\hline & \multicolumn{4}{|c|}{$\mathrm{RCP} 4.5$} & \multicolumn{4}{|c|}{ RCP 8.5} \\
\hline & Irrca & Irrrc & Irrsc & Irrsm & Irrca & Irrrc & Irrsc & Irrsm \\
\hline BEN & 8.72 & 9.73 & 10.24 & 7.70 & 4.49 & 4.86 & 5.43 & 3.87 \\
\hline BFA & 9.57 & 10.54 & 11.03 & 8.59 & 5.06 & 5.57 & 5.91 & 4.48 \\
\hline CIV & 7.17 & 8.18 & 8.69 & 6.16 & 2.94 & 3.32 & 3.87 & 2.32 \\
\hline CMR & 7.33 & 8.36 & 8.87 & 6.31 & 3.25 & 3.82 & 4.23 & 2.59 \\
\hline DZA & 7.89 & 8.71 & 9.12 & 7.07 & 4.29 & 4.78 & 5.04 & 3.79 \\
\hline GIN & 7.81 & 8.84 & 9.35 & 6.78 & 3.23 & 3.72 & 4.16 & 2.61 \\
\hline MLI & 9.16 & 10.10 & 10.57 & 8.22 & 4.83 & 5.31 & 5.65 & 4.28 \\
\hline NER & 8.84 & 9.72 & 10.15 & 7.96 & 4.76 & 5.28 & 5.52 & 4.25 \\
\hline NGA & 7.86 & 8.87 & 9.37 & 6.84 & 3.68 & 4.22 & 4.63 & 3.04 \\
\hline \multirow[t]{2}{*}{ TCD } & 7.74 & 8.77 & 9.29 & 6.70 & 3.69 & 4.26 & 4.69 & 3.02 \\
\hline & \multicolumn{8}{|c|}{ Year 2040-2060 } \\
\hline BEN & 9.03 & 10.38 & 10.60 & 7.96 & 4.60 & 5.24 & 5.57 & 3.95 \\
\hline BFA & 10.05 & 11.19 & 11.60 & 9.01 & 5.26 & 5.87 & 6.17 & 4.65 \\
\hline CIV & 7.44 & 8.99 & 9.05 & 6.42 & 2.78 & 3.41 & 3.73 & 2.15 \\
\hline CMR & 7.56 & 8.75 & 9.14 & 6.51 & 3.57 & 4.23 & 4.57 & 2.90 \\
\hline $\mathrm{DZA}$ & 8.39 & 9.26 & 9.69 & 7.51 & 4.52 & 5.04 & 5.30 & 4.00 \\
\hline GIN & 7.95 & 9.25 & 9.55 & 6.89 & 2.95 & 3.58 & 3.90 & 2.32 \\
\hline MLI & 9.67 & 10.72 & 11.17 & 8.67 & 4.96 & 5.54 & 5.83 & 4.38 \\
\hline NER & 9.48 & 10.40 & 10.89 & 8.54 & 5.09 & 5.64 & 5.91 & 4.54 \\
\hline NGA & 8.18 & 9.34 & 9.75 & 7.13 & 3.96 & 4.61 & 4.94 & 3.30 \\
\hline \multirow[t]{2}{*}{ TCD } & 7.92 & 9.04 & 9.48 & 6.84 & 4.01 & 4.69 & 5.03 & 3.33 \\
\hline & \multicolumn{8}{|c|}{ Year 2060-2080 } \\
\hline BEN & 4.49 & 5.10 & 11.12 & 8.26 & 4.70 & 5.37 & 5.70 & 3.84 \\
\hline BFA & 5.43 & 6.11 & 11.95 & 9.24 & 5.32 & 5.94 & 6.26 & 4.65 \\
\hline CIV & 4.10 & 4.70 & 9.61 & 6.64 & 2.80 & 3.44 & 3.76 & 1.97 \\
\hline CMR & 3.52 & 4.10 & 9.59 & 6.82 & 3.61 & 4.29 & 4.62 & 2.84 \\
\hline DZA & 9.43 & 10.32 & 9.96 & 7.72 & 4.79 & 5.33 & 5.60 & 4.22 \\
\hline GIN & 4.59 & 5.23 & 9.86 & 6.99 & 3.00 & 3.64 & 3.96 & 2.27 \\
\hline MLI & 8.31 & 9.15 & 11.47 & 8.89 & 5.09 & 5.69 & 5.99 & 4.44 \\
\hline NER & 9.14 & 10.03 & 11.10 & 8.72 & 5.25 & 5.82 & 6.10 & 4.68 \\
\hline NGA & 4.57 & 5.19 & 10.13 & 7.38 & 4.06 & 4.73 & 5.06 & 3.31 \\
\hline TCD & 8.81 & 9.68 & 9.90 & 7.17 & 4.09 & 4.78 & 5.12 & 3.30 \\
\hline
\end{tabular}

It shows the total amount of irrigation water requirements by countries of the basin under the RCP 4.5 and the RPC 8.5. A demonstrates mean from 2020 to 2040, B demonstrates mean from 2040 to 2060, C demonstrates mean from 2060 to 2080. Irrca denotes irrigation water requirement of cassava; Irrrc denotes irrigation water requirement of rice and corn; Irrsc denotes irrigation water requirement sugar cane; Irrsm denotes irrigation water requirement of sorghum and millet. BEN denotes Benin, BFA denotes Burkina-Faso, CIV denotes Ivory Coast, CMR denotes Cameroon, DZA denotes Algeria, GIN denotes Guinea, MLI denotes Mali, NER denotes Niger, NGA denotes Nigeria, TCD denotes Chad. 
Table 2. Total irrigation water requirements (IRW) in mm/day under ECHAM.

\begin{tabular}{|c|c|c|c|c|c|c|c|c|}
\hline \multirow{3}{*}{ Country } & \multicolumn{8}{|c|}{ Year 2020-2040 } \\
\hline & \multicolumn{4}{|c|}{ RCP 4.5} & \multicolumn{4}{|c|}{ RCP 8.5} \\
\hline & Irrca & Irrrc & Irrsc & Irrsm & Irrca & Irrrc & Irrsc & Irrsm \\
\hline BEN & 2.80 & 3.42 & 3.74 & 2.17 & 2.64 & 3.27 & 3.58 & 2.01 \\
\hline BFA & 3.49 & 4.11 & 4.42 & 2.87 & 3.35 & 3.97 & 4.28 & 2.74 \\
\hline CIV & 1.91 & 2.51 & 2.81 & 1.31 & 1.86 & 2.47 & 2.77 & 1.25 \\
\hline CMR & 2.62 & 3.25 & 3.56 & 1.99 & 2.61 & 3.24 & 3.55 & 1.98 \\
\hline DZA & 4.88 & 5.43 & 5.70 & 4.33 & 4.83 & 5.37 & 5.65 & 4.28 \\
\hline GIN & 1.85 & 2.45 & 2.76 & 1.25 & 1.77 & 2.38 & 2.68 & 1.17 \\
\hline MLI & 3.84 & 4.44 & 4.74 & 3.24 & 3.86 & 4.46 & 4.76 & 3.26 \\
\hline NER & 4.70 & 5.30 & 5.60 & 4.10 & 4.57 & 5.17 & 5.47 & 3.97 \\
\hline NGA & 2.79 & 3.42 & 3.73 & 2.17 & 2.69 & 3.32 & 3.63 & 2.06 \\
\hline \multirow[t]{2}{*}{ TCD } & 2.63 & 3.25 & 3.57 & 2.00 & 2.59 & 3.22 & 3.54 & 1.96 \\
\hline & \multicolumn{8}{|c|}{ Year 2040-2060 } \\
\hline BEN & 2.71 & 3.34 & 3.65 & 2.09 & 2.67 & 3.30 & 3.62 & 2.04 \\
\hline BFA & 3.50 & 4.12 & 4.43 & 2.87 & 3.34 & 3.96 & 4.28 & 2.71 \\
\hline CIV & 2.05 & 2.66 & 2.97 & 1.44 & 2.13 & 2.74 & 3.05 & 1.51 \\
\hline CMR & 2.78 & 3.42 & 3.74 & 2.15 & 2.86 & 3.49 & 3.81 & 2.22 \\
\hline DZA & 4.83 & 5.38 & 5.65 & 4.28 & 4.88 & 5.43 & 5.70 & 4.33 \\
\hline GIN & 1.96 & 2.57 & 2.87 & 1.35 & 2.02 & 2.63 & 2.94 & 1.40 \\
\hline MLI & 3.92 & 4.53 & 4.83 & 3.32 & 3.78 & 4.39 & 4.69 & 3.17 \\
\hline NER & 4.70 & 5.31 & 5.61 & 4.10 & 4.59 & 5.20 & 5.50 & 3.98 \\
\hline NGA & 2.85 & 3.48 & 3.80 & 2.22 & 2.87 & 3.50 & 3.82 & 2.23 \\
\hline \multirow[t]{2}{*}{$\mathrm{TCD}$} & 2.78 & 3.41 & 3.73 & 2.15 & 2.87 & 3.50 & 3.82 & 2.23 \\
\hline & \multicolumn{8}{|c|}{ Year 2060-2080 } \\
\hline BEN & 2.65 & 3.27 & 3.59 & 2.10 & 2.74 & 3.38 & 3.70 & 2.10 \\
\hline BFA & 3.41 & 4.04 & 4.35 & 2.85 & 3.48 & 4.11 & 4.43 & 2.85 \\
\hline CIV & 1.98 & 2.59 & 2.90 & 1.59 & 2.22 & 2.84 & 3.15 & 1.59 \\
\hline CMR & 2.78 & 3.41 & 3.73 & 2.41 & 3.06 & 3.71 & 4.03 & 2.41 \\
\hline DZA & 4.79 & 5.33 & 5.61 & 4.57 & 5.13 & 5.69 & 5.97 & 4.57 \\
\hline GIN & 1.91 & 2.52 & 2.83 & 1.53 & 2.15 & 2.77 & 3.08 & 1.53 \\
\hline MLI & 3.84 & 4.45 & 4.75 & 3.40 & 4.02 & 4.64 & 4.95 & 3.41 \\
\hline NER & 4.63 & 5.23 & 5.54 & 4.13 & 4.74 & 5.36 & 5.67 & 4.13 \\
\hline NGA & 2.77 & 3.40 & 3.72 & 2.33 & 2.97 & 3.62 & 3.94 & 2.33 \\
\hline TCD & 2.78 & 3.42 & 3.74 & 2.42 & 3.07 & 3.72 & 4.05 & 2.42 \\
\hline
\end{tabular}

It shows the total amount of irrigation water requirements by countries of the basin under the RCP 4.5 and the RPC 8.5. Same as Table 1. 
Table 3. Total irrigation water requirements (IRW) in mm/day under MIROC 5.

\begin{tabular}{|c|c|c|c|c|c|c|c|c|}
\hline \multirow{3}{*}{ Country } & \multicolumn{8}{|c|}{ Year 2020-2040 } \\
\hline & \multicolumn{4}{|c|}{ RCP 4.5} & \multicolumn{4}{|c|}{ RCP 8.5} \\
\hline & Irrca & Irrrc & Irrsc & Irrsm & Irrca & Irrrc & Irrsc & Irrsm \\
\hline BEN & 0.22 & 0.24 & 0.25 & 0.20 & 18.90 & 20.94 & 21.96 & 16.86 \\
\hline BFA & 0.23 & 0.25 & 0.26 & 0.21 & 17.71 & 19.65 & 20.63 & 15.76 \\
\hline CIV & 0.23 & 0.25 & 0.26 & 0.21 & 17.32 & 19.36 & 20.37 & 15.29 \\
\hline CMR & 0.23 & 0.25 & 0.26 & 0.21 & 20.94 & 23.49 & 24.77 & 18.40 \\
\hline DZA & 0.25 & 0.27 & 0.28 & 0.22 & 20.03 & 22.44 & 23.65 & 17.63 \\
\hline GIN & 0.23 & 0.25 & 0.26 & 0.21 & 17.22 & 19.23 & 20.23 & 15.21 \\
\hline MLI & 0.23 & 0.25 & 0.27 & 0.21 & 17.46 & 19.47 & 20.48 & 15.45 \\
\hline NER & 0.23 & 0.25 & 0.26 & 0.21 & 18.08 & 20.11 & 21.12 & 16.05 \\
\hline NGA & 0.23 & 0.25 & 0.26 & 0.20 & 20.06 & 22.36 & 23.52 & 17.75 \\
\hline \multirow[t]{2}{*}{ TCD } & 0.23 & 0.25 & 0.26 & 0.21 & 21.44 & 23.91 & 25.14 & 18.97 \\
\hline & \multicolumn{8}{|c|}{ Year 2040-2060 } \\
\hline BEN & 0.22 & 0.25 & 0.26 & 0.20 & 18.95 & 20.99 & 22.01 & 16.90 \\
\hline BFA & 0.23 & 0.25 & 0.26 & 0.21 & 17.98 & 19.92 & 20.90 & 16.03 \\
\hline CIV & 0.23 & 0.25 & 0.26 & 0.21 & 17.53 & 19.57 & 20.59 & 15.49 \\
\hline CMR & 0.24 & 0.26 & 0.27 & 0.21 & 20.85 & 23.41 & 24.69 & 18.29 \\
\hline DZA & 0.25 & 0.27 & 0.28 & 0.23 & 20.54 & 22.94 & 24.16 & 18.07 \\
\hline GIN & 0.23 & 0.25 & 0.26 & 0.21 & 17.48 & 19.50 & 20.51 & 15.46 \\
\hline MLI & 0.24 & 0.26 & 0.27 & 0.22 & 17.87 & 19.90 & 20.91 & 15.85 \\
\hline NER & 0.24 & 0.26 & 0.27 & 0.21 & 18.44 & 20.48 & 21.50 & 16.40 \\
\hline NGA & 0.23 & 0.25 & 0.26 & 0.21 & 19.89 & 22.21 & 23.36 & 17.60 \\
\hline \multirow[t]{2}{*}{ TCD } & 0.23 & 0.25 & 0.26 & 0.21 & 21.41 & 23.90 & 25.14 & 18.95 \\
\hline & \multicolumn{8}{|c|}{ Year 2060-2080 } \\
\hline BEN & 0.23 & 0.25 & 0.26 & 0.21 & 19.00 & 21.05 & 22.08 & 16.96 \\
\hline BFA & 0.23 & 0.25 & 0.26 & 0.21 & 18.36 & 20.32 & 21.30 & 16.40 \\
\hline CIV & 0.23 & 0.25 & 0.27 & 0.21 & 17.74 & 19.79 & 20.82 & 15.70 \\
\hline CMR & 0.24 & 0.26 & 0.27 & 0.22 & 21.29 & 23.88 & 25.17 & 18.70 \\
\hline DZA & 0.25 & 0.28 & 0.29 & 0.23 & 21.12 & 23.59 & 24.82 & 18.66 \\
\hline GIN & 0.24 & 0.26 & 0.27 & 0.21 & 17.80 & 19.83 & 20.84 & 15.76 \\
\hline MLI & 0.24 & 0.26 & 0.27 & 0.22 & 18.38 & 20.43 & 21.45 & 16.34 \\
\hline NER & 0.24 & 0.26 & 0.27 & 0.22 & 18.80 & 20.85 & 21.87 & 16.75 \\
\hline NGA & 0.23 & 0.25 & 0.26 & 0.21 & 20.22 & 22.56 & 23.72 & 17.89 \\
\hline TCD & 0.23 & 0.25 & 0.27 & 0.21 & 21.88 & 24.40 & 25.66 & 19.37 \\
\hline
\end{tabular}

It shows the total amount of irrigation water requirements by countries of the basin under the RCP 4.5 and the RPC 8.5. Same as Table 1.

\section{Conclusions}

The fifth most-produced seed globally, sorghum, is an incredibly important crop in African countries. It is used in several different dishes. In West Africa, Nigeria was the leading producer of sorghum in 2013. Indeed, sorghum production in Nigeria surpasses that of all other crops, and sorghum has considerable sustainable and economically profitable potential. In 2009 , approximately $70 \%$ of sorghum production was used for local 
consumption, almost 30\% was used for cattle feed, and less than $1 \%$ was used for international trade. Notably, Burkina-Faso is the third-largest producer of sorghum on the African continent after Nigeria and Sudan.

The north of the Niger basin is desert and very arid, temperatures are very high, and rainfall is infrequent. According to all the models, this area will consume a huge amount of water for irrigation. Mali and Niger will have to plan an agricultural strategy if they want to produce foods in this area. Sorghum and millet are the crops consuming the least amount of water for irrigation; followed by cassava, then rice and corn, and finally sugar cane. However, the choice of the best model requires the uncertainty associated with the selection of models. Other knowledge and methods of selection are essential in selecting the best models. This study provides a global idea of the variation of the IWR in the Niger River basin in the next sixty years.

According to the different models, the different results of the IWR are mainly due to the difference in the resolution of the data of the different models. Indeed the data provided by the different models have large resolutions [56]. Given the multiple relief over which the Niger river basin extends, climatic data with less than $25 \mathrm{~km}$ resolutions are necessary for an adequate climatic representation [56]. However, GCMs fail to provide adequate resolution [74]; they provide rough results and general spatial information. Advanced GCMs, coupled with a regional circulation model to give high-resolution output [75] or downscaling methods with particular attention to topographic effects [76], can solve the insufficient spatial resolution of meshed climate data describing future climates.

The essential IWRs are preceded by the RCP 4.5 of the MROC5 model, which predicts an IWR of $16.3 \mathrm{~mm}$ / day, and the RCP 4.5 of the CSIRO model predicts an IWR of $45.9 \mathrm{~mm} /$ day. These significant amounts of IWR will be particularly observed in Mali, Niger, Algeria, and rarely in Burkina Faso (depending on the model RCP4.5 and 8.5 of the CSIRO model). The lowest quantities of IWRs are preceded by the RCP 4.5 of the Miroc5 model which will be $1.29 \mathrm{~mm} /$ day, the RCP 4.5 of the CSIRO model predicts $33.4 \mathrm{~mm} /$ day Guinea, the Southern Mali, Ivory Coast, the center and south of Nigeria and Cameroon are the zones where the lowest quantity will be observed. However, the sugar cane will be the crop with the highest IWR according to the model's prediction, and it will consume an IWR between $0.25 \mathrm{~mm}$ /day (Benin in 2020-2040) and $25.66 \mathrm{~mm} /$ day (Chad in 2060-2080). According to model forecasts, millet will be the culture that will possess the lowest IWR, its quantity of irrigation water will be between $0.20 \mathrm{~mm} /$ day (Benin from 2020 to 2060) and $19.37 \mathrm{~mm}$ / day (Chad in 2060-2080) according to the prediction of models.

Thus, with this study, countries belonging to the Niger River basin can adopt robust policies with further research in water resources and agriculture sectors, thus ensuring good essential crop production. It would also be of great interest to these countries to reduce the quantity of water used to produce plants grown for export in the future.

Author Contributions: Conceptualization, A.O.A., Y.A.H. and H.L.; Data curation, A.O.A.; Formal analysis, A.O.A. and Y.A.H.; Funding acquisition, H.L.; Methodology, A.O.A.; Software, A.O.A.; Supervision, H.L.; Validation, A.O.A., Y.A.H. and H.L.; Writing-original draft, A.O.A. and Y.A.H.; Writing-review \& editing, A.O.A., H.L., Y.A.H. and Y.Z. All authors have read and agreed to the published version of the manuscript.

Funding: This research is supported by National Key Research and Development Program (grant Nos. 2019YFC1510504); NNSF (grant Nos. 41830752, 42071033, and 41961134003).

Acknowledgments: The authors thank the reviewers and editors for their valuable comments about the manuscript.

Conflicts of Interest: The authors declare no conflict of interest.

\section{References}

1. Piao, S.; Ciais, P.; Huang, Y.; Shen, Z.; Peng, S.; Li, J.; Zhou, L.; Liu, H.; Ma, Y.; Ding, Y.; et al. The impacts of climate change on water resources and agriculture in China. Nature 2010, 467, 43. [CrossRef] 
2. $\quad$ Rahim, S.; Xu, J.; Hameed, F.; Khalil, A.; Wei, Q.; Cai, S.; Wenhuan, B.; Hamoud, Y. Spatiotemporal deviation in growing degree days and season under increasing temperature in heilongjiang province. Pak. J. Agric. Sci. 2019, 56, 1075-1086.

3. Kotir, J.H. Climate change and variability in Sub-Saharan Africa: A review of current and future trends and impacts on agriculture and food security. Environ. Dev. Sustain. 2011, 13, 587-605. [CrossRef]

4. Wu, T.; Zhang, W.; Jiao, X.; Guo, W.; Hamoud, Y.A. Comparison of five Boosting-based models for estimating daily reference evapotranspiration with limited meteorological variables. PLoS ONE 2020, 15, e0235324. [CrossRef] [PubMed]

5. Schmidhuber, J.; Tubiello, F.N. Global food security under climate change. Proc. Natl. Acad. Sci. USA 2007, 104, 19703-19708. [CrossRef] [PubMed]

6. Oumarou Abdoulaye, A.; Lu, H.; Zhu, Y.; Alhaj Hamoud, Y.; Sheteiwy, M. The global trend of the net irrigation water requirement of maize from 1960 to 2050. Climate 2019, 7, 124. [CrossRef]

7. Serdeczny, O.; Adams, S.; Baarsch, F.; Coumou, D.; Robinson, A.; Hare, W.; Schaeffer, M.; Perrette, M.; Reinhardt, J. Climate change impacts in Sub-Saharan Africa: From physical changes to their social repercussions. Reg. Environ. Chang. 2017, 17, 1585-1600. [CrossRef]

8. Dai, A.; Trenberth, K.E. Estimates of freshwater discharge from continents: Latitudinal and seasonal variations. J. Hydrometeorol. 2002, 3, 660-687. [CrossRef]

9. Ogilvie, A.; Mahé, G.; Ward, J.; Serpantié, G.; Lemoalle, J.; Morand, P.; Barbier, B.; Tamsir Diop, A.; Caron, A.; Namarra, R.; et al. Water, agriculture and poverty in the Niger River basin. Water Int. 2010, 35, 594-622. [CrossRef]

10. Ebi, K.L.; Ogden, N.H.; Semenza, J.C.; Woodward, A. Detecting and attributing health burdens to climate change. Environ. Health Perspect. 2017, 125, 085004. [CrossRef] [PubMed]

11. Pecl, G.T.; Araújo, M.B.; Bell, J.D.; Blanchard, J.; Bonebrake, T.C.; Chen, I.-C.; Clark, T.D.; Colwell, R.K.; Danielsen, F.; Evengård, B. Biodiversity redistribution under climate change: Impacts on ecosystems and human well-being. Science 2017, 355, eaai9214. [CrossRef]

12. Myers, S.S.; Smith, M.R.; Guth, S.; Golden, C.D.; Vaitla, B.; Mueller, N.D.; Dangour, A.D.; Huybers, P. Climate change and global food systems: Potential impacts on food security and undernutrition. Annu. Rev. Public Health 2017, 38, 259-277. [CrossRef]

13. Caney, S. Human rights, responsibilities, and climate change. In Environmental Rights; Routledge: London, UK, $2017 ;$ pp. 117-137.

14. Moazenzadeh, R.; Mohammadi, B. Assessment of bio-inspired metaheuristic optimisation algorithms for estimating soil temperature. Geoderma 2019, 353, 152-171. [CrossRef]

15. Xiao, G.; Zheng, F.; Qiu, Z.; Yao, Y. Impact of climate change on water use efficiency by wheat, potato and corn in semiarid areas of China. Agric. Ecosyst. Environ. 2013, 181, 108-114. [CrossRef]

16. McVicar, T.R.; Roderick, M.L.; Donohue, R.J.; Li, L.T.; Van Niel, T.G.; Thomas, A.; Grieser, J.; Jhajharia, D.; Himri, Y.; Mahowald, N.M.; et al. Global review and synthesis of trends in observed terrestrial near-surface wind speeds: Implications for evaporation. J. Hydrol. 2012, 416-417, 182-205. [CrossRef]

17. Murphy, J.M.; Sexton, D.M.H.; Barnett, D.N.; Jones, G.S.; Webb, M.J.; Collins, M.; Stainforth, D.A. Quantification of modelling uncertainties in a large ensemble of climate change simulations. Nature 2004, 430, 768. Available online: https: / www.nature. com/articles/nature02771\#supplementary-information (accessed on 11 April 2020). [CrossRef] [PubMed]

18. Fischer, G.; Tubiello, F.N.; van Velthuizen, H.; Wiberg, D.A. Climate change impacts on irrigation water requirements: Effects of mitigation, 1990-2080. Technol. Forecast. Soc. Chang. 2007, 74, 1083-1107. [CrossRef]

19. Lesley, H.; Michael, A.; Helen, M.; Stephanie, T. Climate change and Australia. Wiley Interdiscip. Rev. Clim. Chang. 2014, 5, 175-197. [CrossRef]

20. Kapetanaki, G.; Rosenzweig, C. Impact of climate change on maize yield in central and northern Greece: A simulation study with CERES-Maize. Mitig. Adapt. Strateg. Glob. Chang. 1997, 1, 251-271. [CrossRef]

21. Konzmann, M.; Gerten, D.; Heinke, J. Climate impacts on global irrigation requirements under 19 GCMs, simulated with a vegetation and hydrology model. Hydrol. Sci. J. 2013, 58, 88-105. [CrossRef]

22. Döll, P. Impact of climate change and variability on irrigation requirements: A global perspective. Clim. Chang. 2002, 54, 269-293. [CrossRef]

23. Al-Ghobari, H.M.; Dewidar, A.Z. Deficit irrigation and irrigation methods as on-farm strategies to maximize crop water productivity in dry areas. J. Water Clim. Chang. 2017, 9, 399-409. [CrossRef]

24. Lehn, H.; Simon, L.M.; Oertel, M. Climate Change Impacts on the Water Sector. In Climate Adaptation Santiago; Krellenberg, K., Hansjürgens, B., Eds.; Springer: Berlin/Heidelberg, Germany, 2014; pp. 59-79. [CrossRef]

25. Lengoasa, J. Climate variability and change: Impacts on water availability. Irrig. Drain. 2016, 65, 149-156. [CrossRef]

26. Novoa, D.C. Hydro-economic analysis for water resources management in a changing climate. In Climate Change and the Sustainable Use of Water Resources; Springer: Berlin/Heidelberg, Germany, 2012; pp. 127-141.

27. Babel, M.S.; Agarwal, A.; Shinde, V.R. Climate Change Impacts on Water Resources and Selected Water Use Sectors. Clim. Chang. Water Resour. 2014, 22, 109.

28. Hamoud, Y.A.; Shaghaleh, H.; Sheteiwy, M.; Guo, X.; Elshaikh, N.A.; Khan, N.U.; Oumarou, A.; Rahim, S.F. Impact of alternative wetting and soil drying and soil clay content on the morphological and physiological traits of rice roots and their relationships to yield and nutrient use-efficiency. Agric. Water Manag. 2019, 223, 105706. [CrossRef]

29. Frenken, K.; Gillet, V. Irrigation Water Requirement and Water Withdrawal by Country; FAO: Rome, Italy, 2012. 
30. Rodríguez Díaz, J.A.; Weatherhead, E.K.; Knox, J.W.; Camacho, E. Climate change impacts on irrigation water requirements in the Guadalquivir river basin in Spain. Reg. Environ. Chang. 2007, 7, 149-159. [CrossRef]

31. Hamoud, Y.A.; Guo, X.; Wang, Z.; Shaghaleh, H.; Chen, S.; Hassan, A.; Bakour, A. Effects of irrigation regime and soil clay content and their interaction on the biological yield, nitrogen uptake and nitrogen-use efficiency of rice grown in southern China. Agric. Water Manag. 2019, 213, 934-946. [CrossRef]

32. Aghelpour, P.; Mohammadi, B.; Biazar, S.M. Long-term monthly average temperature forecasting in some climate types of Iran, using the models SARIMA, SVR, and SVR-FA. Theor. Appl. Climatol. 2019. [CrossRef]

33. Seo, S.B.; Kim, Y.-O.; Kim, Y.; Eum, H.-I. Selecting climate change scenarios for regional hydrologic impact studies based on climate extremes indices. Clim. Dyn. 2019, 52, 1595-1611. [CrossRef]

34. Yukimoto, S.; Adachi, Y.; Hosaka, M.; Sakami, T.; Yoshimura, H.; Hirabara, M.; Tanaka, T.Y.; Shindo, E.; Tsujino, H.; Deushi, M.; et al. A New Global Climate Model of the Meteorological Research Institute: MRI-CGCM3 —Model Description and Basic Performance-. J. Meteorol. Soc. Jpn. Ser. II 2012, 90A, 23-64. [CrossRef]

35. Nerem, R.S.; Beckley, B.D.; Fasullo, J.T.; Hamlington, B.D.; Masters, D.; Mitchum, G.T. Climate-change-driven accelerated sea-level rise detected in the altimeter era. Proc. Natl. Acad. Sci. USA 2018, 115, 2022-2025. [CrossRef] [PubMed]

36. Clapp, J.; Newell, P.; Brent, Z.W. The global political economy of climate change, agriculture and food systems. J. Peasant Stud. 2018, 45, 80-88. [CrossRef]

37. Tol, R.S. The economic impacts of climate change. Rev. Environ. Econ. Policy 2018, 12, 4-25. [CrossRef]

38. Hsiang, S.; Kopp, R.; Jina, A.; Rising, J.; Delgado, M.; Mohan, S.; Rasmussen, D.; Muir-Wood, R.; Wilson, P.; Oppenheimer, M. Estimating economic damage from climate change in the United States. Science 2017, 356, 1362-1369. [CrossRef] [PubMed]

39. Zhang, P.; Zhang, J.; Chen, M. Economic impacts of climate change on agriculture: The importance of additional climatic variables other than temperature and precipitation. J. Environ. Econ. Manag. 2017, 83, 8-31. [CrossRef]

40. Estrada, F.; Botzen, W.W.; Tol, R.S. A global economic assessment of city policies to reduce climate change impacts. Nat. Clim. Chang. 2017, 7, 403. [CrossRef]

41. Hallegatte, S.; Rozenberg, J. Climate change through a poverty lens. Nat. Clim. Chang. 2017, 7, 250. [CrossRef]

42. Sonwa, D.J.; Dieye, A.; El Mzouri, E.-H.; Majule, A.; Mugabe, F.T.; Omolo, N.; Wouapi, H.; Obando, J.; Brooks, N. Drivers of climate risk in African agriculture. Clim. Dev. 2017, 9, 383-398. [CrossRef]

43. Weber, T.; Haensler, A.; Rechid, D.; Pfeifer, S.; Eggert, B.; Jacob, D. Analyzing regional climate change in africa in a 1.5, 2, and 3 C global warming world. Earth's Future 2018, 6, 643-655. [CrossRef]

44. Karandish, F.; Mousavi, S.S.; Tabari, H. Climate change impact on precipitation and cardinal temperatures in different climatic zones in Iran: Analyzing the probable effects on cereal water-use efficiency. Stoch. Environ. Res. Risk Assess. 2016, 31, 2121-2146. [CrossRef]

45. Jones, M.R.; Singels, A.; Ruane, A.C. Simulated impacts of climate change on water use and yield of irrigated sugarcane in South Africa. Agric. Syst. 2015, 139, 260-270. [CrossRef]

46. Cammarano, D.; Ronga, D.; Di Mola, I.; Mori, M.; Parisi, M. Impact of climate change on water and nitrogen use efficiencies of processing tomato cultivated in Italy. Agric. Water Manag. 2020, 241, 106336. [CrossRef]

47. Kashyap, P.S.; Panda, R.K. Evaluation of evapotranspiration estimation methods and development of crop-coefficients for potato crop in a sub-humid region. Agric. Water Manag. 2001, 50, 9-25. [CrossRef]

48. Allen, R.; Pereira, L.; Raes, D.; Smith, M. Crop evapotranspiration guidelines for computing crop requirements. FAO Irrig. Drain. Report modeling and application. J. Hydrol. 1998, 285, 19-40.

49. Djaman, K.; O’Neill, M.; Owen, C.; Smeal, D.; Koudahe, K.; West, M.; Allen, S.; Lombard, K.; Irmak, S. Crop Evapotranspiration, Irrigation Water Requirement and Water Productivity of Maize from Meteorological Data under Semiarid Climate. Water 2018, 10, 405. [CrossRef]

50. Singh Rawat, K.; Kumar Singh, S.; Bala, A.; Szabó, S. Estimation of crop evapotranspiration through spatial distributed crop coefficient in a semi-arid environment. Agric. Water Manag. 2019, 213, 922-933. [CrossRef]

51. Zhao, T.; Wang, Q.J.; Schepen, A.; Griffiths, M. Ensemble forecasting of monthly and seasonal reference crop evapotranspiration based on global climate model outputs. Agric. For. Meteorol. 2019, 264, 114-124. [CrossRef]

52. Nations, U. United Nations Millennium Development Goals Report 2012; United Nations: New York, NY, USA, 2012.

53. Mancosu, N.; Snyder, R.; Kyriakakis, G.; Spano, D. Water Scarcity and Future Challenges for Food Production. Water 2015, 7, 975-992. [CrossRef]

54. Fitton, N.; Alexander, P.; Arnell, N.; Bajzelj, B.; Calvin, K.; Doelman, J.; Gerber, J.S.; Havlik, P.; Hasegawa, T.; Herrero, M.; et al. The vulnerabilities of agricultural land and food production to future water scarcity. Glob. Environ. Chang. 2019, 58, 101944. [CrossRef]

55. Porkka, M.; Gerten, D.; Schaphoff, S.; Siebert, S.; Kummu, M. Causes and trends of water scarcity in food production. Environ. Res. Lett. 2016, 11, 015001. [CrossRef]

56. Thomas, A. Agricultural irrigation demand under present and future climate scenarios in China. Glob. Planet. Chang. 2008, 60, 306-326. [CrossRef]

57. Oguntunde, P.G.; Abiodun, B.J. The impact of climate change on the Niger River Basin hydroclimatology, West Africa. Clim. Dyn. 2013, 40, 81-94. [CrossRef]

58. Abdel-Kabirou, B.; Weihua, Z.; Chaofu, W. Irrigation water requirements of rice using Cropwat model in Northern Benin. Int. J. Agric. Biol. Eng. 2015, 8, 58-64. [CrossRef] 
59. Muchara, B.; Ortmann, G.; Mudhara, M.; Wale, E. Irrigation water value for potato farmers in the Mooi River Irrigation Scheme of KwaZulu-Natal, South Africa: A residual value approach. Agric. Water Manag. 2016, 164, 243-252. [CrossRef]

60. Altchenko, Y.; Villholth, K.G. Mapping irrigation potential from renewable groundwater in Africa-A quantitative hydrological approach. Hydrol. Earth Syst. Sci. Discuss. 2015, 19, 1055-1067. [CrossRef]

61. Valipour, M. Future of agricultural water management in Africa. Arch. Agron. Soil Sci. 2015, 61, 907-927. [CrossRef]

62. Dzikiti, S.; Volschenk, T.; Midgley, S.J.E.; Lötze, E.; Taylor, N.J.; Gush, M.B.; Ntshidi, Z.; Zirebwa, S.F.; Doko, Q.; Schmeisser, M.; et al. Estimating the water requirements of high yielding and young apple orchards in the winter rainfall areas of South Africa using a dual source evapotranspiration model. Agric. Water Manag. 2018, 208, 152-162. [CrossRef]

63. Descroix, L.; Mahé, G.; Lebel, T.; Favreau, G.; Galle, S.; Gautier, E.; Olivry, J.C.; Albergel, J.; Amogu, O.; Cappelaere, B.; et al. Spatio-temporal variability of hydrological regimes around the boundaries between Sahelian and Sudanian areas of West Africa: A synthesis. J. Hydrol. 2009, 375, 90-102. [CrossRef]

64. Deryng, D.; Elliott, J.; Folberth, C.; Müller, C.; Pugh, T.A.M.; Boote, K.J.; Conway, D.; Ruane, A.C.; Gerten, D.; Jones, J.W.; et al. Regional disparities in the beneficial effects of rising CO2 concentrations on crop water productivity. Nat. Clim. Chang. 2016, 6, 786-790. [CrossRef]

65. Smith, M. CROPWAT: A Computer Program for Irrigation Planning and Management; Food and Agriculture Organization of the United Nations: Rome, Italy, 1992.

66. Döll, P.; Siebert, S. Global modeling of irrigation water requirements. Water Resour. Res. 2002, 38, 8-1-8-10. [CrossRef]

67. Allen, R.G.; Pereira, L.S.; Raes, D.; Smith, M. Crop evapotranspiration-Guidelines for computing crop water requirements-FAO Irrigation and drainage paper 56. Faorome 1998, 300, D05109.

68. Hawkins, E.; Sutton, R. The potential to narrow uncertainty in regional climate predictions. Bull. Am. Meteorol. Soc. 2009, 90, 1095-1108. [CrossRef]

69. Hawkins, E.; Sutton, R. The potential to narrow uncertainty in projections of regional precipitation change. Clim. Dyn. 2011, 37, 407-418. [CrossRef]

70. Knutti, R.; Sedláček, J. Robustness and uncertainties in the new CMIP5 climate model projections. Nat. Clim. Chang. 2013, 3, 369-373. [CrossRef]

71. Zhou, T.; Wu, P.; Sun, S.; Li, X.; Wang, Y.; Luan, X. Impact of future climate change on regional crop water requirement-A case study of Hetao Irrigation District, China. Water 2017, 9, 429. [CrossRef]

72. Schlenker, W.; Lobell, D.B. Robust negative impacts of climate change on African agriculture. Environ. Res. Lett. 2010, 5, 014010. [CrossRef]

73. Knox, J.; Hess, T.; Daccache, A.; Wheeler, T. Climate change impacts on crop productivity in Africa and South Asia. Environ. Res. Lett. 2012, 7, 034032. [CrossRef]

74. Hulme, M.; Wigley, T.; Jiang, T.; Zhao, Z.-C.; Wang, F.; Ding, Y.; Leemans, R.; Markham, A. Climate Change due to the Greenhouse Effect and its Implications for China; WWF: Gland, Switzerland, 1992.

75. Paeth, H.; Born, K.; Podzun, R.; Jacob, D. Regional dynamical downscaling over West Africa: Model evaluation and comparison of wet and dry years. Meteorol. Z. 2005, 14, 349-367. [CrossRef]

76. Leung, L.R.; Ghan, S.J. Parameterizing subgrid orographic precipitation and surface cover in climate models. Mon. Weather Rev. 1998, 126, 3271-3291. [CrossRef] 